\title{
Obsidian and Early Cultural Contact in the Near East
}

\author{
By Colin Renfrew \\ Department of Ancient History, University of Sheffield \\ and \\ J. E. Dixon and J. R. CANN \\ Department of Mineralogy and Petrology, Cambridge
}

\section{INTRODUCTION}

$\mathrm{O}$ BSIDIAN was not necessarily the earliest object of trade, but it certainly seems to be the first for which material evidence remains. It has been reported from nearly every Early Neolithic settlement in the Near East, although many of these sites are distant from the natural sources.

In our first paper (Cann and Renfrew I964), we outlined a method for the characterization, by trace-element analysis, of obsidian artifacts from archaeological contexts. This allowed the determination of the natural sources from which the material derived. In that paper, however, only the west Mediterranean region was considered in sufficient detail to give definitive results. The obsidian trade in the Aegean has subsequently been studied in detail also (Renfrew, Cann and Dixon 1965$)$.

In the present paper, the obsidian trade in the Near East is examined. This topic is particularly important since obsidian seems to be the most promising approach towards understanding the extent to which the different Early Neolithic cultural and ecological regions were in contact. It should help to suggest how the early spread in the knowledge and use of animal and plant domesticates took place in the Near East.

The method of analysis of the obsidian-the determination of trace elements by optical spectrography ${ }^{1}$-is the same as that previously used. It is further described in Cann, Dixon and Renfrew (forthcoming).

The first important step is the sorting of the analyses into groups. The many new analyses now available confirm all the groups established in 1964 , and these can now be defined with greater precision. Several new groups have now been added, making a total of eight for the regions under discussion. In the first section (below), the division into groups is discussed in some detail.

\footnotetext{
${ }^{1}$ We are again extremely grateful to Dr S. R. Nockolds of the Department of Mineralogy and Petrology, Cambridge, for permission to use the Department's spectrograph, and to Mr R. S. Allen for assistance in its use. We would like also to acknowledge grants received from St. John's College, Cambridge and the Research Fund of the University of Sheffield towards expenses incurred in the work. The maps were kindly drawn by $\mathrm{Mr} H$. A. Shelley.
} 


\section{Colin Renfrew, J. E. Dixon and J. R. Cann. Obsidian and Early Cultural Contact in the Near East}

Previously only two sources of obsidian in the Near East had been reported, with adequate documentation, in the archaeological literature. Six sources can now be correlated with the groups established, and they are discussed in the second section. In the remaining sections, the important archaeological implications of the new evidence are discussed.

\section{DIVISION OF ANALYSES INTO GROUPS}

The specimens analysed from the Near Eastern region, including Anatolia, are listed in Table I (Provenance) and Table II (Analysis). The findspots are shown on the maps, figs. I and 3. The order followed in each table is the same, the specimens being listed in the order of the groups previously established, as elaborated below. The specimens were selected so as to include as many as possible from the known source regions, as well as from early archaeological contexts. ${ }^{1}$

Details of the appearance of each specimen have also been recorded. This, taken in isolation, can be a very misleading guide to the composition or origin of obsidian. For example, red and black mottling is rarely seen in obsidian, but these analyses have shown that it does in fact occur occasionally at many of the sources, and the feature is thus of no diagnostic value. On the other hand a green colour in transmitted light proves to be a frequent (although not a necessary) property of peralkaline obsidians, which are of rare occurrence. It has therefore been used (Cann and Renfrew 1964, fig. 6) to distinguish the obsidian from Pantelleria, a peralkaline source, and that from Lipari, in early strata on Malta. In the Near Eastern region the only source of peralkaline obsidian is Nemrut Dağ on Lake Van, so that a similar separation in warranted.

The obsidians have been divided up, so far as is possible, into groups. Ideally each group would correspond uniquely to a single source, so that all the products of that source would fall, on analysis, into the group. In practice one group may contain material from more than one source, and this complicates the interpretation of the results. However, in the Near East, the pattern of sources and groups is fortunately a simple one, and few difficulties arise.

Criteria are thus required which will serve to class together in one group all the specimens derived from a single source, while distinguishing specimens from other sources. The homogeneity of single sources - the constancy of analysis of specimens from different parts of a single source-is an important factor. This has already been demonstrated in detail for the Lipari source, and more recently, for both the Melian sources (Renfrew, Cann and Dixon 1965). Table II shows that the same is true for the Near Eastern sources which it has been possible to test extensively. Karakapu, near Hasan Dağ (nos. 26r to 268 of group rh), Çiftlik, near Melendiz Dağ (nos. 270 to 276 of group 2b), Acigöl (nos. 156 to 159,269 of

\footnotetext{
1 We are very grateful to all those scholars, listed by name in Table I, who have supplied us with material fot analysis. In addition we have recelved valuable assistance or advice from the following: Professor E. Bostanci. Professor R. J. Braidwood, Mr Gavin Btown, Dr G. H. S. Bushriell, M. Jacques Cauvin, Professor J. G. D, Clark, M. Henti de Contenson, M. Jacques Courtois, Miss M. Cra'ster, Mr David French, Mr Michael Gough, Dr Fratik Hole, Professior S. A. Karisy, Dr Y. Karageorghis, Professor M. E. L. Mallowan, Mr James Mellaart, Mr Peder Mortensen, Mr M. Motrabet, Miss Stephanie Page, Di G. Pasguare, Mrs J. Crowfoot Payne, Mr Sebastinin Payne, M. Jean Petrot, Mr A. Renftew, Mr E. S. Sellers, Mr Ian Todd.
} 


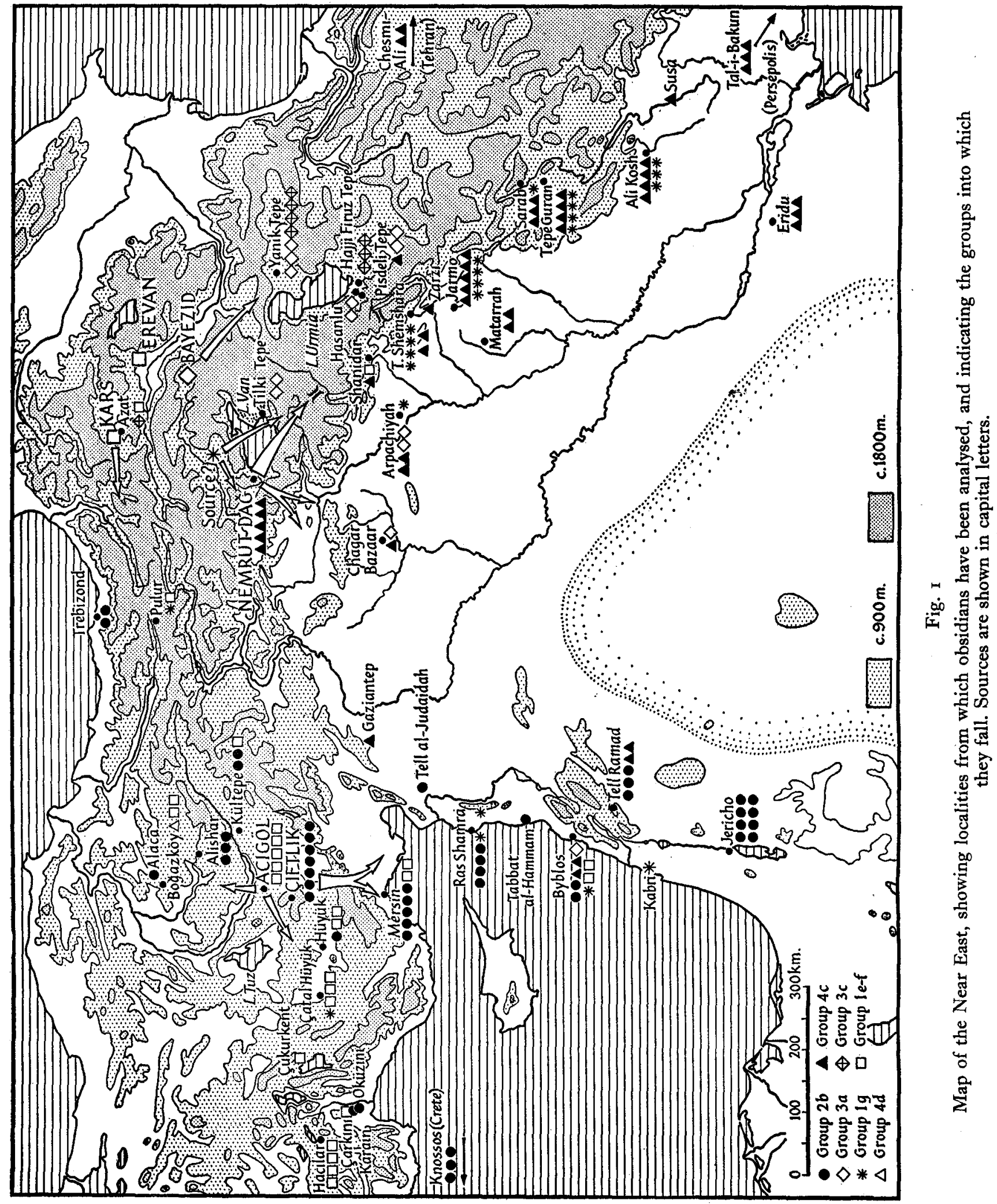


group Ie-f) and Nemrut Dağ (nos. 8I to 83, I60, I6r of group 4c) all show a high degree of internal consistency. This is a very important first result of the analyses, for unless the samples from a single source were notably similar no useful information could be gleaned from the analyses.

The barium and zirconium figures from the analyses of Table $I$ have been plotted on fig. 2 in the same manner as the results in our previous papers. The plotted points can be seen to fall into several groups. All of the groups previously recognized for Near Eastern obsidians are represented, and three new groups make their appearance. Where several analyses are available for a single welldocumented source, these fall within a single group; all the specimens from the source at Çiftlik fall within group 2b, those from Acigöl and Karakapu together with others from Armenia, fall within group I, and those from the sources at Nemrut Dağ in group $4 \mathrm{c}$ (compare fig. 2 with the results in Table II).

Several groups previously established (groups $2 a, 3 b, 4 a, 5$ and 6 ) are not represented in the Near East, apparently being restricted in the Old World to Africa and the west Mediterranean.

Group I. The specimens of this group are high in barium (greater than $300 \mathrm{ppm}$.) and have a low or moderate content of zirconium (less than $300 \mathrm{ppm}$.). It may be seen from the diagram that this group may be divided into three sub-groups, $\mathrm{rh}$ (low in zirconium), $\mathrm{Ig}$ (high in zirconium), and Ie-f, lying between the two. These sub-groups prove to have a strong correlation with different sources.

Group $\mathrm{Ih}$, as well as being divided by barium and zirconium, is distinguished by characteristically low contents of lanthanum and rubidium. All of the specimens in this group come from the source at Karakapu, south of Hasan Dă̆ in Cappodocia.

Group $\mathrm{Ig}$ is distinguished by its high zirconium, and also by a low content of strontium and a high one of iron. The close compositional convergence of this group is very noteworthy (Table II). The possible location of the source for this group is discussed below; it must lie in Armenia. But it is not yet clear whether the single specimen of this group from Early Neolithic Çatal Hüyük (no. 4r) really derives from Armenia, or if it may conceivably be an anomalous and exceptional product of a nearer source. It would be wrong to put too much weight on a single determination, and more analyses are needed to clarify the matter.

The residue of group I has been designated group re-f. It contains examples from two sources, Acigöl in Cappodocia (nos. 156 to 159, 269) and the Kars district of Armenia (nos. 28 and 29). At present we see no way of distinguishing these, so that attribution of a specimen to group re-f is less useful for the archaeological interpretation than to other groups.

Group $2 b$. This group was distinguished in our first paper, and the present analyses serve only to confirm its identity. It is centred on a barium content of about 200 and a zirconium content of $30 \mathrm{ppm}$. Again the convergence in chemical composition is very strong. It represents obsidian from the source at Çiftlik in Cappodocia.

Group 3. The specimens of this group fall on the barium-zirconium graph between those of group $2 \mathrm{~b}$ and those of group $4 \mathrm{c}$. The specimens of group $3 \mathrm{a}$ contain higher zirconium and generally higher barium, yttrium and iron than those of group $3 \mathrm{c}$. The source for both of these groups must lie in east Armenia. Two specimens that fall in group $3 \mathrm{c}$ on the barium-zirconium graph (nos. I7I, Ras Shamra, and 235, Dahran) have been distinguished as group $3 \mathrm{~d}$, on the basis of an exceptionally high content of rubidium and lithium. It is not yet clear whether these are from an otherwise undocumented source, possibly in Armenia, or are anomalous analyses from known sources. The analyses of group 3 are not so closely convergent as those of other groups.

Group 4. This group contains obsidians with barium contents generally less than $3 \circ \mathrm{ppm}$., and zirconium contents varying up to over $\mathrm{I}, 000 \mathrm{ppm}$. In the Near East only three of the sub-groups of 
No. 2

group 4 are represented (and these may easily be distinguished on chemical grounds from the subgroups $4 \mathrm{a}$ and $4 \mathrm{~b}$ ). Group $4 \mathrm{f}$ is represented solely by material from the source at Karinyarik Kepez in Cappodocia. It is distinguished by its extremely low content of barium and zirconium.

Group $4 \mathrm{c}$ is characterized by a moderate to high zirconium content. The specimens from this group are very frequently green in transmitted light. The source for this group is Nemrut Dağ in Armenia.

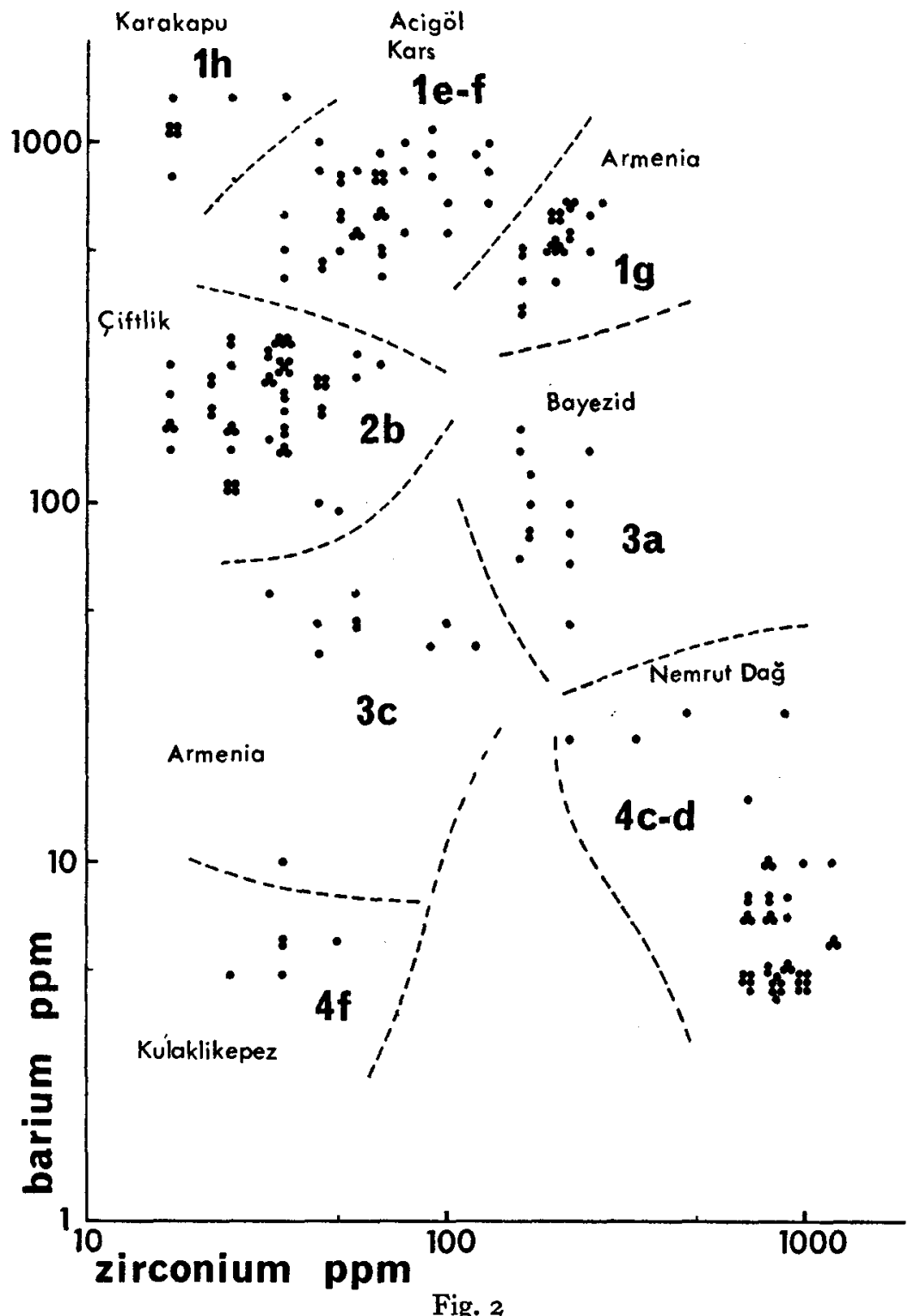

The division of the obsidians analysed into groups, on the basis of the amounts of barium and zirconium present in each. Each dot represents a single sample. The division is supported by a consideration of the other trace-elements present. 
Colin Renfrew, J. E. Dixon and J. R. Cann. Obsidian and Early Cultural Contact in the Near East

Group $4 \mathrm{~d}$ is distinguished from group $4 \mathrm{c}$ on the basis of yttrium and niobium content, as was explained in our first paper. In the present series of analyses, it is represented only by no. 295 from Boğazköy.

The specimens are thus divided into eight groups or sub-groups. Seven of the groups are to be equated with single sources, and only one has material from more than one source, classed together. Detailed information concerning the sources themselves, which these groups represent, is not available in all cases. Indeed in the early stages of the work, the analyses contributed more information bearing on the location of the sources than vice versa. For example, after the first series of analyses early in 1963 (cf. Cann and Renfrew 1964) it was clear that Jericho was importing obsidian in Pre-pottery Neolithic 'A' times. On the basis of surface finds from Bor (no. $9^{8}$ of group $2 \mathrm{~b}$ ) and Gazi (no. I02) it seemed that the source must lie in Cappodocia. But it was not until the autumn of that year that samples were collected for us by Mr A. Renfrew from Çiftlik in Cappodocia, which proved to be the source in question.

However, the analyses and the topographical information at present available do allow a clear if tentative picture of the sources to be established.

\section{THE SOURCES}

The known sources of obsidian in the Near East are restricted to two areas (figs. I and 3): east Anatolia with Armenia, from Lake Van to Erevan, and the district west of Kayseri in south Anatolia, formerly known as Cappodocia.

It is first necessary, however, to consider whether other sources, as yet unknown, might exist. Obsidian is found only in areas of recent volcanic activity, where acid rocks are found. Not all volcanic regions, therefore, are possible sources, and it would seem, for example, that the Jebel Druz area of Syria, where the igneous rocks are predominantly basic in composition, is not a likely one for obsidian sources. However, one has to face the possibility that unknown sources may conceivably exist, and in addition, that through a particularly unfortunate chance the trace element composition might be confusingly like that of sources already known.

There are, however, three lines of argument which, taken together, make the existence of further sources, outside the stated regions, very unlikely. First the increase in geological surveying in recent years, particularly by the oil companies, has increased the level of geological knowledge considerably. Mr D. C. Ion of the British Petroleum Company has kindly written to say that the geological staff, neither of B.P. nor of I.P.C. know of natural occurrences of obsidian in Syria, Iraq, Jordan, Lebanon or Israel. Dr G. Pasquaré, of the Maden Tektik ve Arama Enstitüsü, Ankara, has kindly informed us that he knows of no sources in other areas of Turkey than those discussed below. Nor have the enquiries and observations of archaeologists in the Near East produced evidence for any further obsidian sources other than the possibility, as yet unconfirmed, of an outcrop near Rezaiyeh, west of Lake Urmia. ${ }^{1}$ The volcanoes in south Anatolia, cited by Mellaart (I96r, b, 6o), do not in fact seem to be sources of obsidian.

\footnotetext{
1 Private communication Professor R. J. Braidwood, April r963, and Dr Frank Hole, November 1965, who do not, however, have direct knowledge of this reported source.
} 
The second approach is by the analyses themselves. They can at times be very useful in indicating the existence of sources as yet unlocated. This was the case with the group $2 \mathrm{~b}$ source, as described above, and is still the case for two

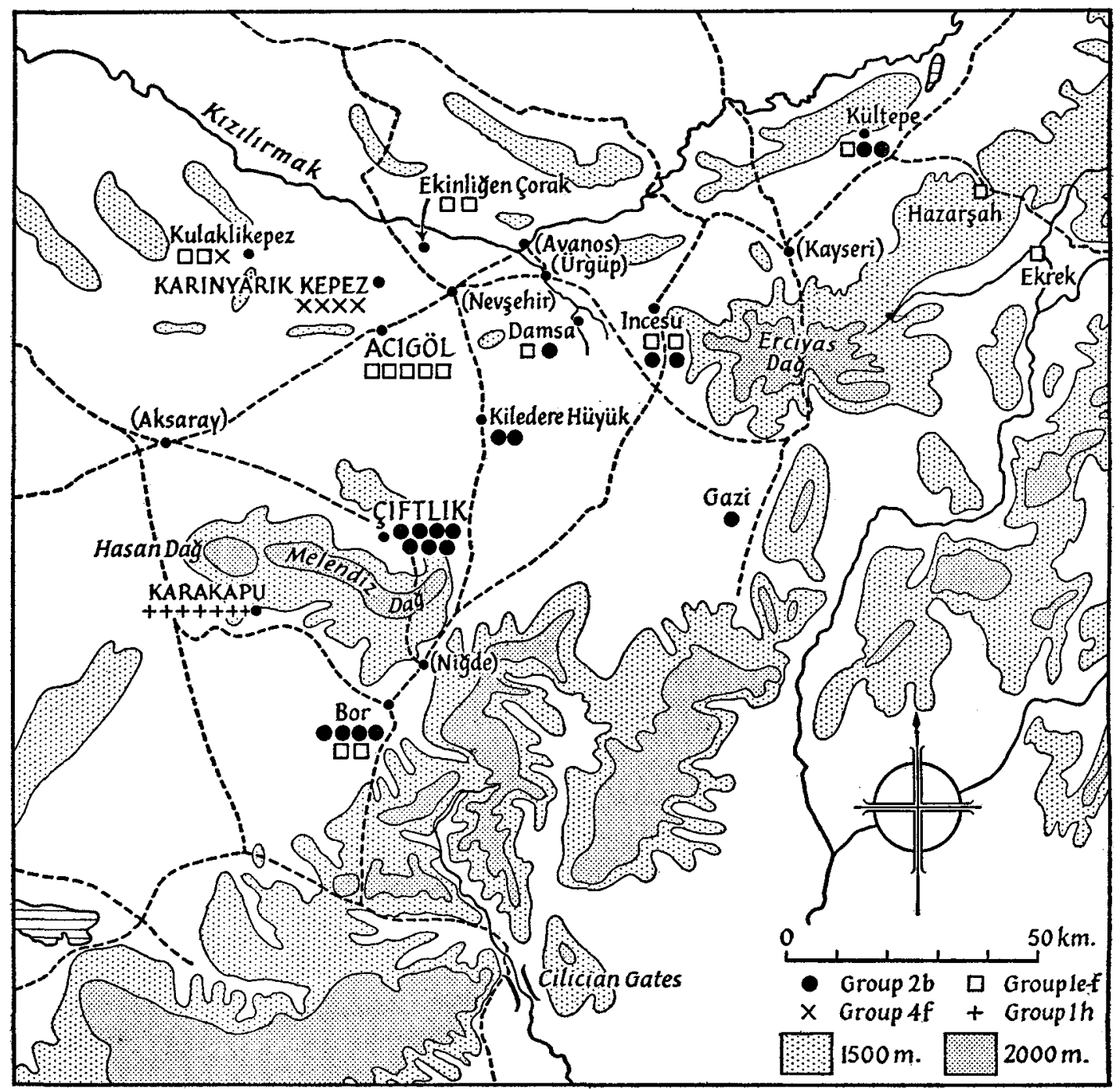

Fig. 3

Map of the source area in Cappodocia, showing the sources (capital letters) and the localities from which samples have been analysed.

unlocated sources, groups Ig and $3 \mathrm{c}$, which on the grounds of distribution are to be set in Armenia.

Finally, the distribution and density of archaeological finds is a very valuable indication of the distance to a workable source of obsidian. The proportion of 
Colin Renfrew, J. E. Dixon and J. R. Cann. Obsidian and Early Cultural Contact in the Near East

obsidian in the total chipped stone industry, for obvious reasons, tends to vary inversely with the distance from the nearest source (fig. 6). Detailed figures are given in Appendix A.

For example, at Early Neolithic Çatal Hüyük, some 200 kilometres from the nearest source, obsidian forms consistently more than $9 \circ$ per cent of the chipped stone assemblage. In the Zagros area of Iraq, the Late Neolithic and Chalcolithic levels at Tell Shemshara, $25^{\circ}$ kilometres from the source at Lake Van, have more than 80 per cent obsidian.

On the other hand at Beidha in Jordan, some 800 kilometres from the Cappodocian sources, only three pieces of stratified obsidian were found in a chipped stone assemblage of some 30,000 pieces from the 'Pre-pottery Neolithic' 'B' level. Equally, at Ali Kosh, I,ooo kilometres from Lake Van, where obsidian is commonest in the Early Neolithic phases, it does not form more than 2 per cent of the assemblage.

Anyone who has surveyed for sites or looked for obsidian in the Kayseri region of Anatolia or in south Greece will testify how abundantly it is to be found. On the other hand in Jordan, or in Thrace, far from the known sources, finds are exceedingly rare. It is the great scarcity of obsidian, therefore, throughout the Near East, with the exception of Cappodocia and Armenia, together with their neighbouring regions, which is the best argument for the absence of natural sources from all but these areas of particular abundance.

Western Anatolia presents special problems, since obsidian from Melos, the source in the Cycladic islands, has been found at various sites at or near the coast (Renfrew, Cann and Dixon 1965). During 1965 Mr Sebastian Payne visited the areas of the supposed sources at Düvertepe (Renfrew, Cann and Dixon 1965, 229) and between Assos and Ayvacik. He found only chert at the latter. At Düvertepe, although glassy rock was found, which might well be termed obsidian in the geological sense, there was certainly none of workable quality. It seems likely that the outcrop reported by Akkus (1962) is likewise not of workable quality. ${ }^{1}$ Finds of obsidian artifacts are rare in west Anatolia, and it is surely significant that the analyses from Hacilar (nos. 277 to 279 of group re-f) conform closely to those from Cappodocia. It would be interesting to have analyses of the artifacts found at Kusura in the Afyon region (Lamb 1936, 43), likewise in west Anatolia. But meanwhile it seems reasonable to conclude that there is no source of workable obsidian between Cappodocia and those of Melos and Giali.

To the north of the regions considered in this paper, in the Caucasus, obsidian sources are known, but the argument of distribution of artifact-finds militates against sources east or south of the Zagros range of western Iran. Only three pieces of obsidian are known to us from central Iran: two from Chasmah-Ali (nos. I88 and 189 of group 4c), and one from Sialk (Ghirshmann 1938, 22 and pl. lv, 7); and there is one from further east, at Anau in Turkestan (Pumpelly, I908, I8I). There can be no sources in these areas. Finds are rare also in southern Iran, while during the entire course of operations of the Danish expedition on the

\footnotetext{
${ }^{1}$ We are indebted to $\mathrm{Mr}$ Gavin Brown for this reference.
} 
Persian Gulf (Gløb and Bibby I96o), only a single piece of obsidian has been found (no. 235 of group 3 d, from Dahran).

The consideration of the sources can thus be restricted to the two principal areas.

\section{A. Cappodocia}

Acigöl-Topada. The best known source in the Cappodocia area, and indeed the only one to have been reported in print ${ }^{1}$ is that located some 8 kilometres east of Acigöl-Topada, II kilometres south-west of Nevşehir, on the Aksaray road. It was mentioned by the late John Garstang and by Mr M. C. Burkitt (Garstang 1953, I5), and visited by Professor H. E. Wright and Dr B. Howe in 1955 (Braidwood and Howe 1960, 23). Professor Braidwood and Professor Wright have kindly sent specimens for analysis which were collected during this visit (nos. I 56 to 158 of group re-f). The source was again visited in 1963 by $\mathrm{Dr}$ G. Pasquaré (nos. 159, 269) and subsequently by $\mathrm{Mr}$ Ian Todd $(1965,14)$. Professor Wright has kindly sent the following account: "The site is on the north side of the road, opposite a high volcano that lies south of the road. The obsidian beds form two hogbacks one-half mile apart near the head of the Acisucay River, which has exhumed them from a cover of white rhyolitic tuff. The eastern of the two ridges is about 50 feet high and consists of I- to 6-inch layers of obsidian and pumiceous rhyolite. Most of the obsidian is black, with or without grey amygdules. About 5 per cent of the obsidian is brown or laminated brown and black. The western of the two ridges is about 100 feet high and is one half-mile north of the road; no brown obsidian was apparent on this ridge'.

The analyses from this source all fall within group re-f, and it seems extremely likely that this was the natural source for all the artifacts from Cappodocia falling in this group. There is, however, another group re-f source in the Kars district of Armenia, so that for finds made outside the immediate source areas, we have no way of discriminating between them. The proportion from the Acigöl source is high in nearby surface finds such as those from Incesu (nos. 244 and 245), Ekinliğen Çorak (253 and 254), Damsa (259), etc. - these sites are indicated on fig. 3 .

The first evidence for the use of the material is given by the finds at Early Neolithic Catal Hüyük (nos. 42, 43, 280) and Mersin (nos. 39, 357), and it continued to be visited until Hittite times at least (cf. nos. 290, 294). Its products have not been found south of Byblos, and were not exported as widely or as early as those of the Çiftlik source (see below). All those specimens from Hacilar that have been analysed are from this source, and it may be that the obsidian found at Kusura in western Anatolia has the same origin.

Ciftlik. Large unworked lumps of obsidian were collected in 1963 by $\mathrm{Mr}$ A. Renfrew near the village of Çiftlik, which lies about 40 kilometres north-west of Niğde, on the road to Nevşehir. Such lumps are found on both sides of the road and in dry stream beds, about to kilometres south of Çiftlik, on the road to Niğde. These lumps are certainly large enough to serve as cores, and numerous artifacts were also collected in the vicinity.

Analyses (nos. 270 to 276) show the geological hand specimens collected here to belong to group $2 \mathrm{~b}$. The puzzling problem of the location of the group $2 \mathrm{~b}$ source is thus solved. It remains to be established, however, whether an actual flow of obsidian of this group exists in this area, from which these lumps have been carried by erosion. They may, on the other hand, be 'bombs', emitted in their present form by the volcano.

The distribution of surface finds of worked group $2 \mathrm{~b}$ obsidian in this region, at Bor (nos. 98 , I92 to I64), Kiledere Hüyük (nos. 257 and 258), Incesu (nos. 242 and 243), etc., is as might be expected, and there seems no reason to think that other sources of this group remain to be found. The evidence for the earliest use of the source is supplied by numbers $29 \mathrm{I}$ and 292, from Aurignacian Karain and Oküzini respectively. Material originating from it has not yet been identified in the Near East to the west of these sites, located near Antalya, nor east of the Syrian desert. The most striking evidence for its importance in early times is afforded by the Jericho material. All the obsidian

1 The 'obsidian deposits' indicated by Bialor (1962, fig. I) following Mellaart ( $1961, b, 60)$ show outcrops of igneous rocks of recent origin, but not necessarily of obsidian. 


\section{Colin Renfrew, J. E. Dixon and J. R. Cain. Obsidian and Early Cultural Contact in the Near East}

fragments from the 'Pre-pottery Neolithic' level there which have been analysed prove to derive from this source. Early finds are frequent elsewhere in the Levant.

Of some interest also is the series of finds of this material found at Minoan Knossos (Renfrew, Cann and Dixon 1965, 239). Although this variety of obsidian is very rare in Crete, analyses 135,136 and 355 show that it was indeed traded from Cappodocia, perhaps via Cyprus or Byblos.

Karakapu. The little village of Karakapu lies to the south of Hasan Dağ, north-west of Bor on the road from Bor to Ankara (fig. 3). Pieces of unworked obsidian had been collected here by Dr G. Pasquaré, and in 1964 the area was visited by Mr Ian Todd, Mr David Biernoff and Colin Renfrew. Small 'bombs' of obsidian, never more than 5 to ro centimetres in diameter, were found over a wide area on both sides of the road. The villagers indicated that larger pieces were to be found higher up on the slopes of Hasan Dağ, but this has yet to be confirmed.

All the pieces analysed (nos. 26I to 268) belong to group ih. But no artifacts yet analysed prove to be of this group, which seems therefore to have been of no importance in prehistoric times. Probably, as in the case of Antiparos (Renfrew, Cann and Dixon 1965, 239), the lumps are too small for practical use.

Kulaklikepez. Small unworked lumps were collected in 1963 by Dr G. Pasquaré and Mr A Renfrew at Kulaklikepez, 40 kilometres west-north-west of Nevşehir, and at Karinyarik Kepez, 12 kilometres west-north-west of Nevşehir. The analyses constitute a new sub-group, 4 f. But again, no artifacts have been analysed which fall in this group, and it was clearly of no importance for tool-making.

No more sources in the Cappodocia region, beyond these four, are yet known. It remains possible, however, that other sources exist in the Nevşehir-Aksaray-Niğde district, with compositions resembling closely those of the four groups discussed above.

\section{B. ARMENia}

Nemrut Dă̆ (Lake Van). The source of obsidian at Nemrut Dağ, at the west end of Lake Van, has been known for some time to archaeologists (Wainwright 1927). It had already been visited by an expedition (Oswald 1906) which gave specimens to the British Museum (Natural History). Professor H. E. Wright has visited this source, which is accessible by a good jeep road from Tatvan. He observed a bed 4 to 8 feet thick in the north wall of the crater, and states that 'much of the obsidian is full of feldspar phenocrysts, but some clear black and some opaque olive green types (in places interlaminated) were also found'. The obsidian from Nemrut Dağ, like other peralkaline obsidians, is typically green in colour when seen in transmitted light, although this is not always the case. Most specimens analysed by us from the Near East region, and which show this distinctive appearance, thirty-two in number, have proved to be peralkaline and assignable to group 4c. Four pieces with a slight green tinge, however, fell within group ig. The group $4 \mathrm{c}$ pieces originate from this source, perhaps the most important in prehistoric times, and it seems likely that nearly all of the Near Eastern obsidian which shows this green colour derives from Lake Van. Figures and proportions for a number of sites are given in Appendix A.

The source was already known and visited some 30,000 years ago, as sample 303 from Shanidar, Layer $\mathrm{C}$, indicates. It supplied obsidian in considerable quantities to the first villages of the Zagros foothills in the Early Neolithic period (Tell Shemshara, Jarmo, Sarab, Tepe Guran, Ali Kosh), and its products have been found as far south as Tal-i-Bakun B (Persepolis). Although the distribution is concentrated in the area east of the Syrian desert, occasional pieces are found in early levels in the Levant, as nos. 328 and 345 from Upper Pre-pottery Neolithic Tell Ramad testify.

The gigantic blade cores from Tilki Tepe, now in the Ankara Museum, may well be from this source, and certainly it was utilized through the Chalcolithic period and well into the Bronze Age, as indicated by analysis 192 from Susa, and probably the green-coloured cores from the vase-makers' workshop at Alalakh (Woolley 1955, 292).

Other Sources. Sources for both group 1 e-f and group $3^{\mathrm{a}}$ obsidian are known in Armenia. The former are documented by analyses of geological hand specimens from the Kars district (no. 28) and the Erevan region (no. 29). Their precise location is, however, unknown. It should be noted too, 
that it is not possible to distinguish obsidian deriving from these sources from that of Acigöl in Cappodocia, so that finds from intermediate localities, such as Pulur (no. 284) cannot be characterized. Group Ie-f obsidian, however, does not play an important role east of the Syrian desert.

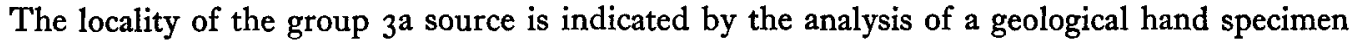
from Bayezid (no. $3^{\circ}$ ). The distribution of finds of group $3^{a}$ makes the location of the source in this area of Armenia a plausible one (fig. 6). The distribution centres on Armenia and the Lake Urmia region, but in Chalcolithic times exports were going westward to Chagar Bazar and Arpachiyah. The material is found even in Middle Neolithic Byblos (no. 317), a site with a very cosmopolitan obsidian supply.

No source is yet known for the obsidian of group ig or of group 3 c. The distribution of finds, however, seems to give a good indication for the probable source regions of both.

Group $3 \mathrm{c}$ obsidian has been found almost exclusively in the Lake Urmia region-at Yanik Tepe and in the Solduz valley (fig. 6). Its distribution is more limited than that of group $3^{a}$, and it seems reasonable to expect the source to lie in east Armenia, perhaps close to Lake Urmia itself.

The distribution of group Ig obsidian centres heavily on the Zagros range. At Tell Shemshara, where over 80 per cent of the lithic industry is obsidian, it would appear that more than half the obsidian is from this source. The source must surely lie somewhere among the acid volcanic rocks of Armenia. Indeed the striking similarity in the distribution of group Ig and group $4 \mathrm{c}$ obsidian, which is known to be from Nemrut Dağ on Lake Van, suggests that the Ig source may not be far from the latter place. Unfortunately, analyses of material from Armenia are few, and it is not possible to be more precise, although the presence of an artifact at Pulur (no. 283) might argue against putting the source too far south.

Like the group $4 \mathrm{C}$ obsidian it is found all along the Zagros from the earliest times. Its occurrence in the Levant, however, is later than is the case for the group $4 \mathrm{c}$ obsidian (Middle Neolithic Byblos, no. 317 ).

Although some obscurities still remain concerning the precise location of some of the obsidian sources, particularly those of Armenia, the overall pattern is clear. It seems likely that sources of workable obsidian in the Near East are limited to the two principal regions, Cappodocia and Armenia. In Cappodocia, sources have been located corresponding to all four of the groups defined. In Armenia sources are known for three of the five groups there located. While there is room for corroboration and further information within these areas, the supply pattern for sites lying well outside them is not likely to be altered significantly by such additional detailed information.

\section{HISTORICAL CONTEXT OF OBSIDIAN ARTIFACTS}

\section{Terminal Hunting and Incipient Domestication}

During Palaeolithic times, obsidian was commonly used in localities where the raw material was freely available. This has long been known for the Upper Palaeolithic of Slovakia (Janšak r935), as for the handaxes of Kenya (Cann and Renfrew 1964, no. 35 of group 4d). Professor Kökten(1952) has published surface finds of Palaeolithic date from Armenia, notably artifacts of Middle Palaeolithic type at Ercis on Lake Van, at Borluk near Kars, and at Yüksekova in the Hakkari region (Kökten 1963, 6r ). Hitherto, however, finds of obsidian artifacts of Palaeolithic date and distant from the natural sources have not been documented.

The earliest stratified finds of obsidian in the Near East are from Layer C of the Shanidar Cave. The Upper Palaeolithic (Baradostian) industry there represented (Solecki 1963$)$ is about 30,000 years old $(28700 \pm 700$ B.P., W-654; $33000 \pm 1000$ B.P., W-650). ${ }^{1}$ Two pieces from this deposit have been analysed

1 All carbon dates are quoted, in accordance with Radiocarbon 7 , on the Libby value for the half-life of C.I $4,5570 \pm 30$ years. 
Colin Renfrew, J. E. Dixon and J. R. Cann. Obsidian and Early Cultural Contact in the Near East

(no. 303 of group $4 c$, and no. 304 of group I e-f). The former, green in colour, is from the source at Nemrut Dag some 300 kilometres distant, a source most easily reached by way of the Hakkari, in which it is interesting to note that

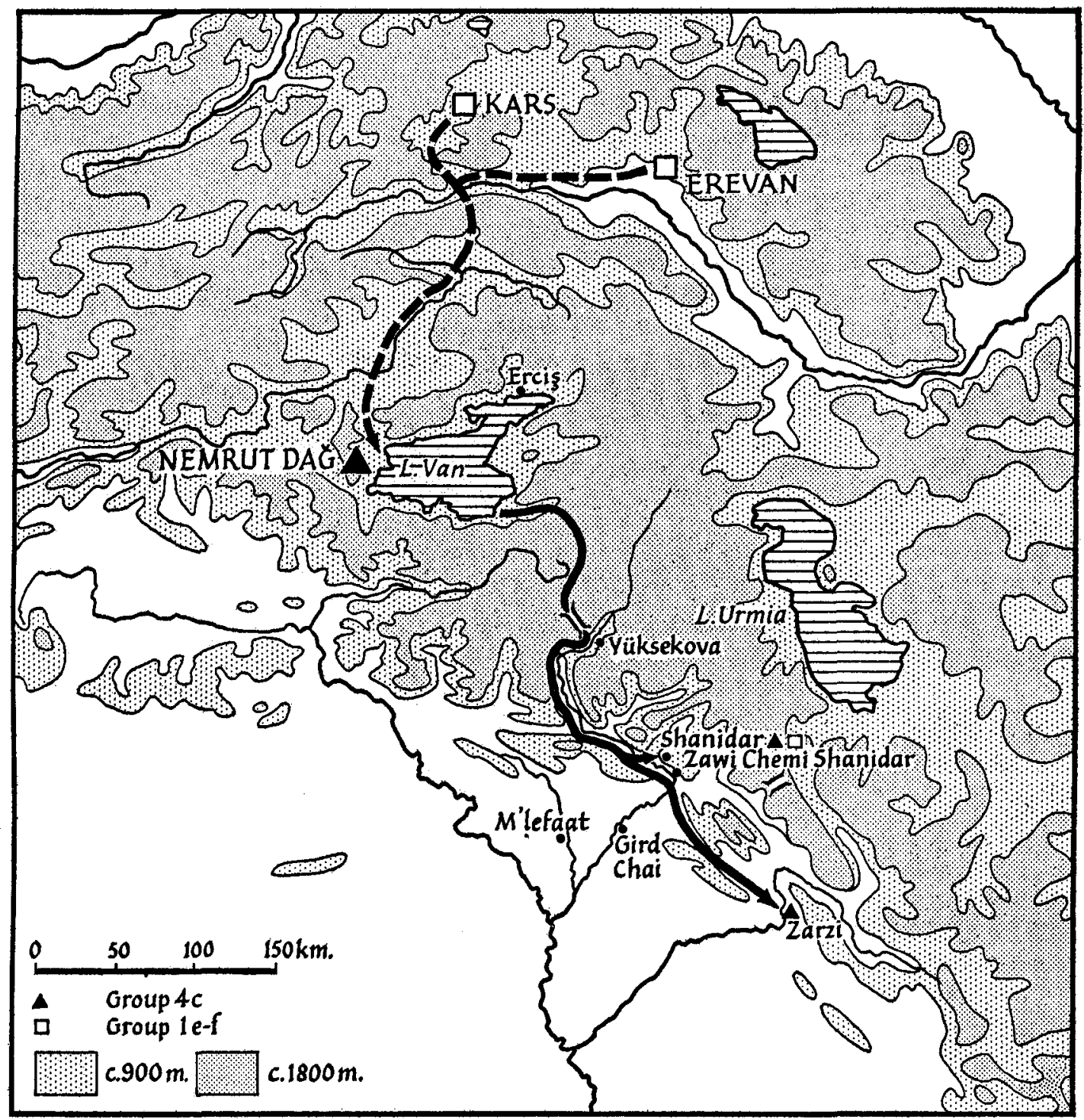

Fig. $4^{\mathrm{a}}$

The Upper Palaeolithic obsidian traffic from Armenia.

Professor Kökten found an obsidian industry with artifacts of Middle Palaeolithic form at the site of Yüksekova. The latter piece is also from Armenia, but from a source further north, in the region of Kars. 
These are rare finds, but they are not unique. Two pieces of obsidian were found by Professor Garrod (1930, 16) during her excavations at the Zarzi cave near the Lesser Zab in Iraqi Kurdistan, some 120 kilometres to the south-east of

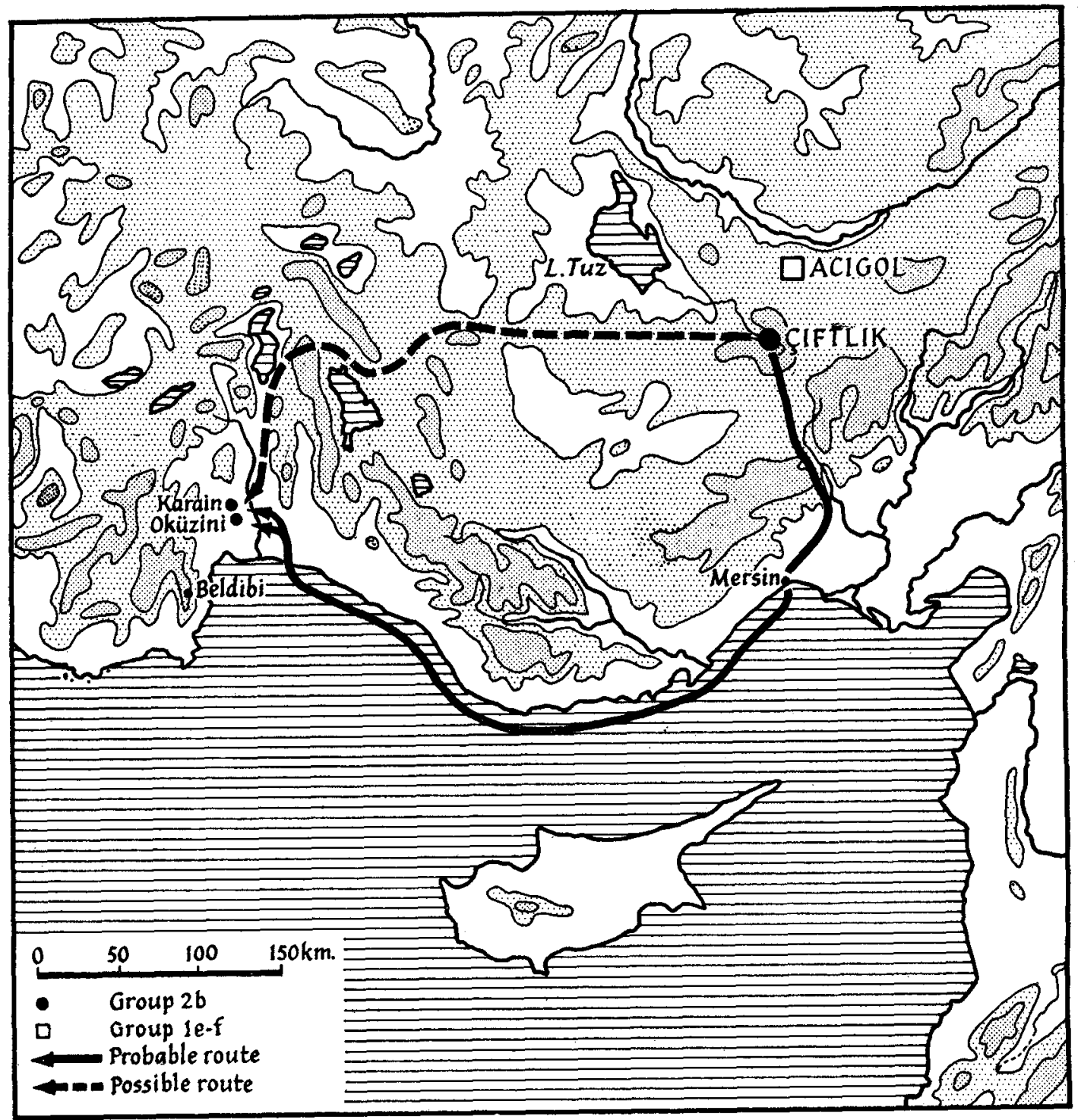

Fig. $4 \mathrm{~b}$

The Upper Palaeolithic obsidian traffic from Cappodocia.

Shanidar and one of these proved on analysis to belong to group $4 \mathrm{c}$, originating from Nemrut Dağ (fig. 4a).

Obsidian was transported over similar distances from the group $2 \mathrm{~b}$ source at Çiftlik near Niğde in Cappodocia (fig. 4 b). One or two pieces have been found in 
the Palaeolithic levels in the caves of the Antalya region (cf. Esin and Benedict I963, 340). Analyses have been carried out on small flakes from the top of the Aurignacian IV level at Oküzini (no. 292) and from the travertine below the Aurignacian IV level at Karain (no. 29I), (Kökten 1963, 70). Radiocarbon determinations are not yet available for these levels, but in view of the microlithic nature of the Beldibi flint industry which has been viewed as intermediate between the Upper Palaeolithic and the Neolithic of south Anatolia (Mellaart 1964, II5) they are likely to antedate 8000 B.c. The analyses show that the group $2 b$ source at Ciftlik was already known at this early date, as may also have been the group Ie-f source at Acigöl, although this is not yet documented.

It is clear, therefore, that very small quantities of obsidian found their way in Upper Palaeolithic times some 400 kilometres from Van over the Hakkari pass and down to Shanidar and Zarzi. From Çiftlik a similar contact is documented over $35^{\circ}$ kilometres across the Taurus and to Antalya. (The route in this case may have been over the Cilician Gates and along the coast, since in the Konya plain, in Neolithic times at least, only group Ie-f obsidian from Acigöl was used.)

Again, it is significant that finds of obsidian show no increase at Mesolithic sites. Not until the first settled farming communities does the material become a commodity of importance. Thus no obsidian whatever was found at Karim Shahir itself (Braidwood and Howe 1960, I82), 'very little' at Zawi Chemi Shanidar (ibid. 183 ) and only six and eight pieces respectively in situ at the contemporary sites of M'lefaat and Gird Chai (ibid. $5 \mathrm{I}$ and 55), again in Iraqi Kurdistan.

No obsidian whatever is known from the Natufian culture, although it appears at Pre-pottery Neolithic 'A' Jericho and related sites. Nor has it been found in the excavations at Beldibi (Bostanci 1959) or Belbași (Bostanci 1962), the only sites in Anatolia where a possible close predecessor for the Konya Early Neolithic has been recognized. Its absence from the 'Mesolithic' levels of these caves, situated near Antalya, is all the more striking in view of its Upper Palaeolithic occurrence in the same region.

It is clear, therefore, that there is no evidence for increased mobility or travel in the early incipient cultivation stage. Only the Karim Shahir culture gives any evidence of contact, and as in the previous terminal food gathering stage, it is small in quantity and restricted in range. No significant developments in patterns of communication are indicated, although the locations of the sources are clearly known. In particular, it is not until the succeeding stage of settled farming and food production that contact of any kind can be documented between south Anatolia and the Levant, or across the Syrian desert.

\section{Settled Farming Communities: 7 Th and 6Th MillenNia}

By the 7 th millennium, settled farming life had developed in the Levant and in the Zagros region. A similar development was soon to take place in south Anatolia. It is a remarkable fact that obsidian is found at virtually all the early village settlement sites excavated. The data on this early obsidian supply are best considered by taking the three principal regions in turn. 
Anatolia. Although the source at Çiftlik was known already in Upper Palaeolithic times, and was supplying the Levant with material from the 8th millennium, it was the group re-f source which served the early sites in central and southern Anatolia. Group 2b obsidian has not been recognized in Neolithic contexts west of Hüyük near Karapinar. Both varieties are found in the earliest levels at Mersin, south of the Cilician Gates.

At Çatal Hüyük, three specimens from the Early Neolithic levels are of group I $\mathrm{e}-\mathrm{f}$ (nos. 42-3, 280). A fourth (no. 4I) falls in group Ig, for which the source is in Armenia, but this is a single and uncorroborated analysis, and little weight can be put on it until further evidence is available. A single specimen analysed from Level IX, a Late Neolithic level, at Hacilar (no. 277) is of group $\mathrm{re}-\mathrm{f}$, as is a surface find from the Late Neolithic site at Cukurkent. Even at Çarkini, near Antalya, where Upper Palaeolithic pieces proved to be of group 2b, a fragment (no. 293) from the Neolithic levels is of group Ie-f. No analyses are yet available from the Early Neolithic site at Suberde (Bordaz I964), or from the other early sites in the region awaiting excavation. At present, however, it would seem that virtually all the obsidian used was from the Cappodocian sources, and that between these, for reasons as yet not understood, Acigöl was favoured.

Not surprisingly, obsidian formed a very high proportion of the total chipped stone industry at early sites not far removed from Acigöl, such as Çatal Hüyük (Appendix A) or Ilicapinar (Mellaart 1958). At later or more distant sites, notably Hacilar or Can Hasan, the ratio of obsidian to flint is lower. At Mersin, nonetheless, it is still very high right into the Halafian period, towards the end of the 6th millennium (Appendix A).

The Zagros Area. The situation at this early time in the Zagros is a simple one (fig. 5). At every Neolithic site investigated, obsidian has been found in quantities which decrease markedly to the south (fig. 7 and Appendix A). Two varieties of obsidian were in general use, and they are found in varying quantities throughout the region. The first is the group $4 \mathrm{c}$ material from the Nemrut Dağ source on Lake Van. It is peralkaline, and is usually green in colour. In the earlier period, notably in the $7^{\text {th }}$ millennium Bus Mordeh and Ali Kosh phases at Ali Kosh, and at Tepe Guran, it was dominant. In the succeeding Mohammad Jaffar phase at Ali Kosh and the more developed Neolithic of Tell Shemshara (Mortensen $1964, b$ ), the second variety takes on a more important role.

This second material, classified as group Ig, is from a source in Armenia which has not yet been precisely located. It is attested already in the Ali Kosh phase at the eponymous site (Hole 1965 ) and in Phase $\mathrm{T}$ at Tepe Guran (Mortensen $1964, a)$. It is notable that no Cappodocian material is found east of the Syrian desert.

By the mid-6th millennium, sites on the Mesopotamian plain were already occupied, and in many of these, such as Matarrah (nos. 202 and 203 of group 4c), Armenian obsidian was in use. It has been found in considerable quantity in the aceramic layers at Bouqras (van Liere and de Contenson, 1963, I82) and samples from this site are at present undergoing analysis. Its later dispersion to sites as distant as Beidha, Tal-i-Bakun and Chasmah-Ali is discussed below. 


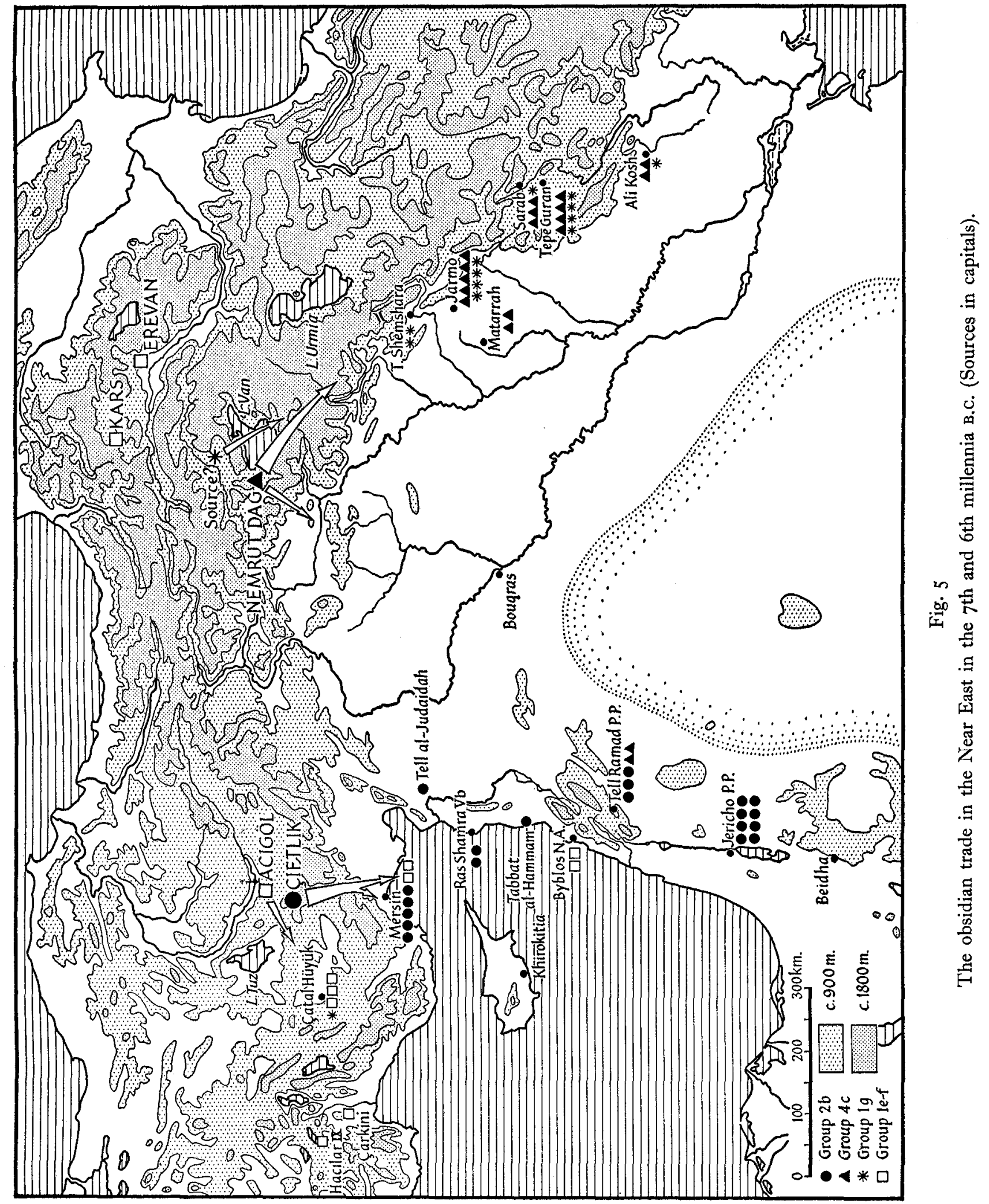


The Levant. The ports of the Levant were dealing at an early date in exotic materials from distant lands. From Halafian times, cities such as Byblos and Ras Shamra were importing obsidian from all quarters (fig. 6). Before the mid6th millennium, however, the picture is a rather simpler one, for the Levant still looked principally to Cappodocia for its obsidian supply.

Again the group $2 \mathrm{~b}$ source at Çiftlik seems to have been the more important at the outset. It was supplying Jericho from Pre-pottery Neolithic ' $A$ ' times (Kenyon 1961), from the 8th millennium B.c. It is surely significant that of the eight specimens analysed from this site, all are of group $2 b$, while group Ie-f is not represented (nos. 50, 5I, 76, 306 to 3 IO). The aceramic levels at Ras Shamra (Schaeffer 1962,158$)$, dated to 6410 B.c. $(\mathrm{P}-460)$ have provided further examples (nos. I69 and I 70 ). So have Tabbat al-Hammam (Hole I958) and Tell al-Judaidah (Braidwood and Braidwood 1960), both from levels corresponding to the Amouq $A$ and $B$ phases, which may be dated by the determination of 6000 B.c. (W-7I6) for basal Mersin. At Mersin itself, group 2b material is found (nos. 40, 165, I66, 20r, 356) together with material of group re-f (nos. 39, 357).

Group re-f material is found both at Mersin and in Early Neolithic Byblos (nos. 172 and 173), a ceramic Neolithic considered by the excavator to be equivalent to basal Mersin and Amouq A-B (Cauvin 1962, 496). Surprisingly perhaps it is not found further afield, even in later periods. However the aceramic Neolithic material of Cyprus (Dikaios 1962, 7I) is now undergoing analysis, and may prove to contain group $\mathrm{Ie}-\mathrm{f}$ as well as group $2 \mathrm{~b}$ material.

Armenian obsidian does not play an important role in the Levant at this early time, although, on the basis of a visual inspection it appears to constitute at least 39 per cent of the aceramic Neolithic obsidian at Bouqras on the Middle Euphrates. From the upper aceramic levels at Tell Ramad, nonetheless (placed by the excavators as equivalent to the Pre-pottery Neolithic ' $\mathrm{B}$ ' at Jericho, and thus datable probably to the end of the 7 th millennium) five obsidians have been analysed. Three were of group $2 \mathrm{~b}$, as was to be expected, but two were of group $4 \mathrm{c}$, deriving from Lake Van. A visual inspection of some forty pieces from Levels I and II at Tell Ramad suggests that less than ro per cent of the obsidian there is of group $4 \mathrm{c}$.

At Beidha, a Pre-pottery Neolithic 'B' site in Jordan (Kirkbride 196r), a single fragment of peralkaline obsidian, now undergoing analysis, has been recognized. It is probably from the Lake Van source also, and supports the conclusion that very small but significant quantities of Armenian obsidian were reaching the Levant in the 7 th millennium B.C.

\section{More Advanced Communities}

Chalcolithic. In the earlier part of the Chalcolithic period at least, the trade in obsidian did not diminish (fig. 6). Finds are common on most Halafian sites, and considerable quantities were found at Arpachiyah and Chagar Bazar. In the northern and central Zagros the proportion of obsidian to flint apparently increases, although in the south, at Ali Kosh in the Deh Luran region, it falls sharply at the end of the Neolithic Mohammad Jaffar phase (Appendix A). 


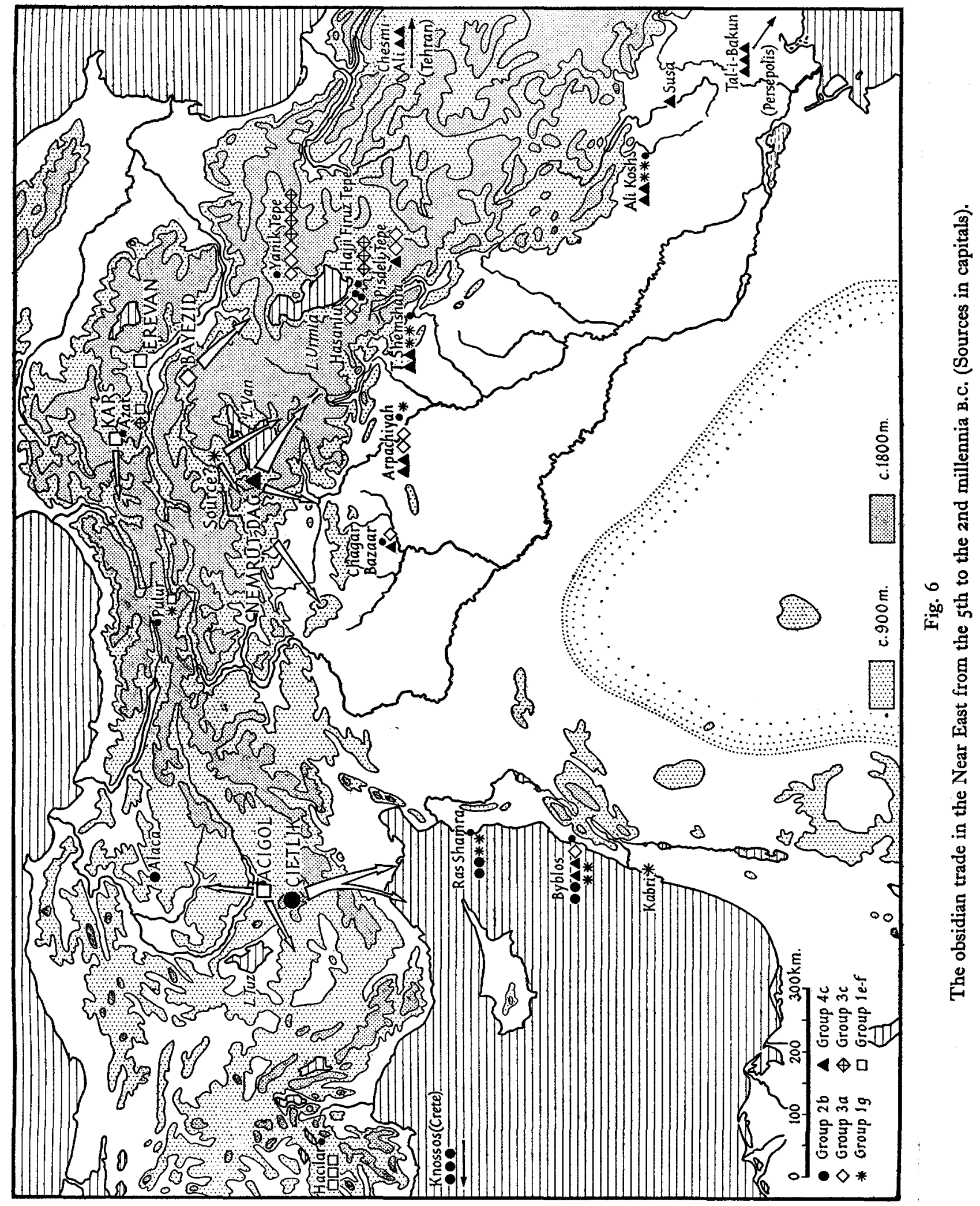


Obsidian is abundant at Mersin until the end of the Halafian period, Levels XX to XVI, and it does not decline therefore until the Ubaid phase. The same is true for Tell al-Judaidah. It is not so common at Late Neolithic Hacilar as it was at Early Neolithic Çatal Hüyük, but this may be due to the greater distance from the sources. That argument is not applicable for Can Hasan, in the Konya plain, and it may be that the decline in the use of obsidian took place earlier in Anatolia then elsewhere in the Near East.

In any case, this decline in the use of obsidian, which correlates largely with the decline in the use of chipped stone in general, must surely be related to the rise of metallurgy in the regions. A notable decrease in the lithic industries was scarcely to be expected until copper or bronze tools-sickles, knives and so forthwere available to fill the same functions.

The obsidian analyses give evidence of a more cosmopolitan and widespread trade from the later 6 th and the $5^{\text {th }}$ millennia than existed earlier. Group $4 \mathrm{c}$ obsidian now travelled from Lake Van as far south as Susa (no. 192) and Tal-iBakun B (Persepolis, nos. 190 and 207). It went east to Pisdeli Tepe in the Solduz valley (no. 327) and Chasmah-Ali in central Iran (nos. I 88 and I89). Westwards the traffic extended to Gaziantep (no. 297) and Byblos (nos. I75 and $3 \mathrm{I} 6$ ). Group Ig obsidian, also from Armenia, had a rather similar distribution, being found also at Ras Shamra in the Ubaid period (nos. 3r3 and 3I4) and at Chalcolithic Kabri in Galilee (no. 305). It may be significant that there was a Halafian outpost on Lake Van itself (Reilly 1940).

Unlike the Armenian obsidian, that of Cappodocia did not at any time cross the Syrian desert - no group $2 \mathrm{~b}$ material has been found east of Trebizond. Finds have been made at Ras Shamra in the Halaf and Ubaid periods (nos. 3 I I and 3I2) as well as at Eneolithic Byblos (no. 315). Much more strikingly, it has been found at Minoan levels at Knossos in Crete (nos. 135, I36, 355) and trade between Knossos and Mersin or some Levantine entrepôt is clearly indicated.

It is at this time that settlements first occur in the Solduz valley, to the south of Lake Urmia. From the outset obsidian is found. At Hajji Firuz Tepe (Cuyler Young 1962), group $3 \mathrm{c}$ obsidian was used in the 6th millennium (nos. I8I and I82), and it continued in use until the Early Bronze Age (nos. 87 and 282) at Yanik Tepe in Azerbaijan (Burney 1964). The very limited distribution of this material testifies to the cultural isolation of the Solduz-Urmia region at this time. In particular there is no evidence of group $3 \mathrm{c}$ obsidian being transported across the Rowanduz pass into the western Zagros area, nor south to the Kermanshah plain, which seem to have been much more closely linked with the western Zagros. At a slightly later date group 3 a obsidian is found at Pisdeli Tepe in the Solduz (nos. 204 and 326) and at Tilki Tepe, and it travelled via Arpachiyah and Chagar Bazar (nos. 46, 80, 85) across to the Levant.

The cosmopolitan nature of this trade is exemplified by such sites as Chagar Bazar and Arpachiyah, the latter with finds of groups Ig, 3a and 4c. Most astonishing of all is the picture given by Byblos, where eight analyses have revealed the presence of obsidian from no fewer than five sources: $1 \mathrm{e}-\mathrm{f}$ and $2 \mathrm{~b}$ in Cappodocia, and Ig, $3 \mathrm{a}$ and $4 \mathrm{c}$ in Armenia. 
By this time too, the attractive qualities of obsidian led to its use for jewellery and fancy goods. The little vase and the pendants from Arpachiyah (Mallowan and Rose, 1933, pl. v, c and xi) have their predecessors in the pendants and obsidian mirrors of Çatal Hüyük (Mellaart 1964, 95 and pl. xxv, c), as well as in the pendants and inlays of Hacilar (Mellaart I96i, a, 46).

Bronze Age. Obsidian blades were still used as tools, such as knives, after the Chalcolithic period, as may be inferred from finds like those of Alaca, Alishar, Boğazköy, Kültepe, Pulur and Azat (see figs. I and 6, and Table I); yet, clearly, they were superseded, for most purposes, by metal ones. The material was, however, much prized, right into the Late Bronze Age, for the manufacture of vases and luxury goods.

The most striking evidence is afforded by the discovery of a vase-maker's workshop at Alalakh on the Orontes River, in the Turkish Hatay (Woolley 1955, 292), with obsidian of two sorts, and some unfinished vases. The recent find by Professor T. Özgüc at Kültepe of a large hoard of obsidian cores from the Late Bronze Age levels suggests the existence of a similar workshop there. Obsidian vases have been found also at Acemhöyük, north-west of Aksaray in Cappodocia, from the Kültepe Ib phase, and two beakers were found in the Early Bronze Age Dorak treasure, together with a shaft-hole axe, a sword hilt and inlay rivets of the same material (Mellaart 1959, fig. Ir, I8D, 20, 21).

Obsidian vases are known from predynastic levels in Mesopotamia (Childe 1954, I I 8; Woolley I956, 71; Tobler I950, 82). They are of frequent occurrence in Late Minoan Crete, where the material is usually an import from the island of Giali (Renfrew, Cann and Dixon 1965, 239). But the celebrated Tylissos rhyton (Hatzidakis 1912, 217) is not of this material, nor is it made of Melian obsidian. Since the obsidian is not green or brown in colour it is not likely to be an import from Egypt, and a Near Eastern origin seems most probable.

The two most striking examples known from the Near East of the high value set upon workmanship in obsidian, are both of Egyptian origin. The first is a toilette table of Egyptian workmanship, and bearing the cartouche of the Hyksos ruler Chian (Stock 1963, 74). It was found at the Hittite capital of Boğazköy, and in this connection the analysis of a small flake from the same site (no. 295 of group 4 d), which likewise proves to be of Egyptian origin, is of some interest.

The discovery of a beautiful obsidian vase and lid, both with gold mountings, in an Egyptian tomb of the xIIth Dynasty at Byblos (Naville 1922, 291; Virolleaud 1922, 273), and other rich finds (Smith 1965,15 and fig. 26) confirm the impression that these objects of Egyptian workmanship were as much prized in the Near East as they were in Egypt. It emphasizes too the remarkable variety, already indicated, of the trading links of Byblos. But obsidian at this time was, of course, only one of a great number of exotic goods traded. These finds indeed emphasize its changed position, from the status of an agricultural necessity to that of an urban luxury. 


\section{TRADE AND CULTURAL CONTACT}

The small quantities of material in question from the earlier prehistoric sites forbid one to speak of organized trade. Indeed, if we are right to assume that Upper Palaeolithic hunters were nomadic and were capable of making occasional movements of several hundred kilometres, it seems reasonable to assume also that they would have had opportunities to acquire small quantities of obsidian in the normal course of events ( $\mathrm{cf}$. Clark 1952, 242). There may also have been some small-scale exchange between groups or individuals, such as we know to have taken place among the Australian aborigines (Clark 1965, b). This would not have been remarkable in itself, but it would be of interest as heralding later developments.

During Neolithic times, more organized systems of supply and exchange certainly came about, but not until the Bronze Age is detailed evidence available for its nature. In any case, there is no reason to suppose that obsidian was the only material traded, or the most important. Obsidian is for us the indicator that contact was taking place, but not necessarily the prime object of such contact. The nature of this traffic and its consequences in the early phases must now be discussed.

Early Mechanisms of Trade and Exchange. Several lines of argument are of value in interpreting the pattern of finds of obsidian in the Neolithic of the Near East. For this time there is no direct historical evidence such as becomesavailable later, and the small amounts of material recovered, and the lack of suitable transport put severe limitations on the scope of trading activities which we may imagine.

In the Upper Palaeolithic period, as indicated above, the finds are so few that no organized system of trade need be put forward to explain them. But the consistent finds of obsidian, albeit in small quantity, at nearly every early settled farming site in the Near East, however distant from the sources, makes necessary an explanation other than nomadic wandering or very casual and haphazard exchange.

Admittedly, for sites distant from the sources, the supply was not a large one, as comparison of the quantities found will show (cf. fig. 7 , and Appendix A). During excavations in 1964 and 1965 at Saliagos near Antiparos in the Aegean, large quantities of worked obsidian were recovered and weighed. At this site, where obsidian was abundantly but not wastefully used, the weight of 1,000 fragments was about 4 kilogrammes. In regions where obsidian is very scarce, the weight would be less, and conversely in source regions, but this figure may be taken as a guide. It is evident therefore that at sites like Jericho or Ali Koshwhere less than I, 500 fragments altogether have been found-obsidian was not imported in great bulk. Even allowing for the partial excavation of these sites, and incomplete recovery of material, such long distance traffic was clearly not a bulk trade. Indeed these small quantities, even admitting that obsidian may not have been the principal commodity of exchange, seem to rule out the existence of specialist traders altogether. 
Colin Renfrew, J. E. Dixon and J. R. Cann. Obsidian and Early Cultural Contact in the Near East

Fortunately there is now considerable evidence that primitive societies, without the services of specialized traders, managed to evolve efficient mechanisms for the acquisition of materials from distant sources (Clark 1965, b). Ceremonial gift exchange, perhaps the most formalized of these, may not be applicable in this case, since obsidian was generally traded as an unworked raw material rather than in the form of attractively finished objects. This is documented by the large amounts of waste material found at most sites, as well as by the fragility of the

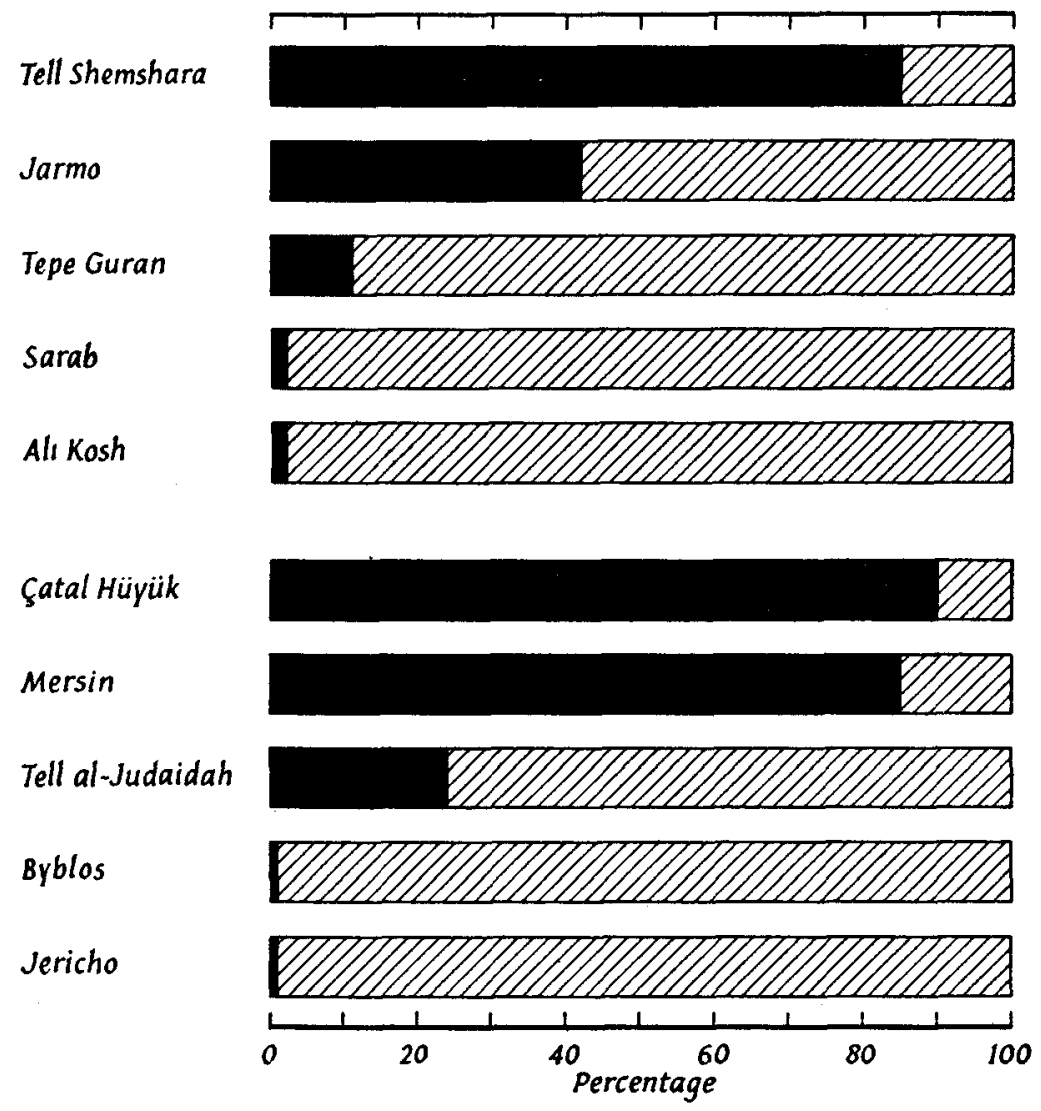

Fig. 7

Proportion of obsidian (black) to flint (shaded) in the chipped stone industry from the 7 th and early 6th millennium levels of Neolithic sites in the Near East (see Appendix A and fig. 5). Finds in the Zagros (above) are from the Armenian sources, whereas those in the Levant (below) derive chiefly from Cappodocia.

finished products, usually in the form of fine blades. The 'silent trade' of the Congo-where the two parties to the exchange do not meet, but place their goods in some predetermined place - is again a rather sophisticated mode of exchange. But nonetheless, the essential factor common to both, that goods and materials travel over great distances without the agency of specialist traders, is of relevance. 
It seems just as likely that the passage of goods across cultural boundaries was effected through systematic exchange in this way as through individual journeys over great distances by 'middlemen'. In both cases there must have been some contact between people and hence between cultures, with consequences whose significance is discussed below.

A system perhaps more efficient and more 'commercial' is indicated for sites such as Tell Shemshara and Jarmo. The 40,000 pieces recovered at Jarmo come from an excavated area of about one twenty-fifth of the total settlement (Braidwood and Howe I960, 39), which therefore may have contained some 4 tons of obsidian altogether. Occasional and regular visits to the sources, probably by specialists, are indicated for such quantities. But the need for full-time professional traders was probably not felt until the development of metallurgy began to make the transport of materials in quantity a crucial problem.

At Catal Hüyük, indeed, the finds of obsidian are so abundant and fine (Appendix A) that specialization in its working is clearly indicated. But since the site is distant only some 200 kilometres from the source at Acigöl which supplied it, there is no need to postulate intermediaries. When obsidian was needed, it was probably fetched direct from the source, perhaps by the craftsmen who made the beautiful mirrors and pressure-flaked daggers. If they did not themselves visit the sources but sent others, these will have been 'traders' in the strict sense that they were specialists in the transport and exchange of materials for gain.

The existence of proprietary rights over source of raw material by local inhabitants has not been documented for prehistoric times. In the case of Melos, it would seem more likely that travellers seeking obsidian simply took what they wanted from the sources (Renfrew, Cann and Dixon 1965, 24I). To clarify this point for Anatolia, it would be necessary to find settlements which, like Tilki Tepe in Chalcolithic times, or Kültepe in the Middle Bronze Age; could have served as places of exchange. The researches of Mr Ian Todd in Cappodocia will probably contribute more useful information on this subject.

It may not have been until the Chalcolithic period, with the inception of the great demand for metals, that organized trade began on a large scale. And with the need for travel over large distances, transport will have become a considerable problem. One would like to imagine specialist merchants, with trains of pack animals, plying between the outpost, located at Tilki Tepe near the obsidian sources on Lake Van, and towns like Arpachiyah, Chagar Bazar and those of Sumer.

The earliest clear evidence for the use of the donkey, horse or half-ass (onager) as a beast of burden is the representation on the Khafaje vase (Zeuner I 963,317 ) which dates from about 3000 B.c. Earlier finds of horse bones from Samarran and Halafian contexts are not thought to indicate domestication. And although the ox was used for traction and as a beast of burden sooner than the equids (ibid., 214) it would not have been suitable for transport over the great distances with which we are concerned here. It would seem that at least in the 7 th and 6th millennia B.c., land traffic was on foot.

The sea, however, was freely used from very early times. Six stratified blades of obsidian were found at aceramic Khirokitia in Cyprus (Dikaios I953, 316) 
and seven at Troulli (Dikaios $1962,7 \mathrm{I}$ ). From the former site there is a radiocarbon date of 5690 B.C. (St. 4I4-I 5), and there was thus already marine traffic between Cyprus and the Near East. Boats were available. Finds of Melian obsidian at Early Neolithic sites on the Greek Mainland, such as Nea Nikomedeia, Sesklo, and Argissa, as well as in the lowest levels at Knossos, corroborate the point, as do analogous finds of Lipari obsidian in the west Mediterranean.

It seems likely, indeed, that trade along the Levantine coast, from Mersin as far south as Jericho, was by sea. But in the Zagros area, and in Anatolia, travel must have been on foot. This clearly set a heavy limitation on the scope of trade before Halafian times-if this is really when equids were domesticated-for a man's profit was limited by what he himself, or perhaps he and his slaves could carry.

Until this time the picture which we can form of trading mechanisms is a conjectural one, based on incomplete evidence. For the Bronze Age, however, we have better sources of information. Written records are then available, which furnish us with details of three different modes of trade, all undertaken by professional merchants. The most apposite of these is certainly the highly organized trade between the Assyrian colonists at the karum of Kültepe in Cappodocia and their Mesopotamian homeland. Ample documents record this efficient and wellorganized trade (Goetze 1957,67 ) and even the routes taken by the trains of pack animals are known. Donkeys were used to carry copper and other raw materials from Cappodocia, returning with burdens of textiles and tin. At relatively so late a time obsidian was not an important commodity, and despite the chance proximity of Kültepe to the Cappodocian sources, it would be easy to make too much of the similarities between this Middle Bronze Age trade and its Chalcolithic predecessors. But there is evidence (Mallowan 1965,2 ) that a similar system was working already in Early Dynastic times.

Well organized trade is documented in the Persian Gulf from about the same period (Oppenheim 1954). Specialist traders from Ur took silver, oil, garments and wool in their ships to Telmun (Bahrein), returning with cargoes of copper, gold, ivory, wood, lapis lazuli and other exotic products. And naturally enough, as well as the sea, the two great rivers were used for communication and trade. Herodotus (I, I94) speaks of the ingenious Armenians who sailed down the Euphrates in skin coracles, each carrying in addition to its cargo of wine, a live donkey. For the return journey, the boats were broken up and the constituent hides loaded onto a donkey, doubtless with a load of gold or some other easily portable material of value.

At this period, one must recognize the coexistence of different modes of trade. It may be worthwhile to distinguish, as Jahn has done for prehistoric Europe (Jahn 1956), between long and short-distance trade, inland and foreign trade, and retail and bulk trade. Moreover amongst the ordinary tools and objects of obsidian, now diminishing in number, some vases stand out as exceptionally fine and exotic. The Byblos vase, the Tylissos rhyton and especially the Boğazköy vessel, may well have been gifts between rulers. Such trade, or exchange, is no longer commerce but diplomacy. 
Cultural Contact and the 'Neolithic Revolution'. The obsidian trade has a significance greater than the simple provision of a substitute material for the production of chipped flints. From the Halafian expansion, a little after 5500 B.C., pottery and other materials, of which obsidian was only one, afford evidence of widespread cultural contacts. Before this time, however, obsidian is one of our very few sources of information.

These patterns of movement in obsidian-from Cappodocia to the Levant and Jericho, and from Armenia along the Zagros to Ali Kosh-evidently indicate contact of some kind, in the 8th to 6th millennia, along routes already familiar to some extent from Upper Palaeolithic times. As discussed above, it is important not to project onto this traffic, or exchange, a complexity and an organization which it did not possess, or to exaggerate the extent of contact which it brought about. Nonetheless it is clear that the inhabitants of one region and environment were already able to draw on the natural resources of a much larger area, and hence, to some extent, on the cultural resources also. These routes were thus also potential channels for the flow and interchange of ideas. Here indeed is their significance, of greater interest even than their role as predecessors or pathfinders for the more organized trade of Early Dynastic times.

The realization that such channels for information were already open at this time and functioning efficiently over such distances must certainly have an impact on our thinking about the origins and development of farming and settled life in the Near East. Early and settled farming communities are known in three principal regions, the Levant, including Jordan, south Anatolia, including the Konya plain, and the Zagros range, with its four early settlement areas (Hole 1962): Iraqi Kurdistan (Jarmo, Tell Shemshara), the Kermanshah plain (Sarab, Tepe Guran), Deh Luran (Ali Kosh) and the Persepolis area. In all of these regions the potential plant and animal domesticates-wild emmer, two-row barley, sheep, goat - were available. Only wild emmer was absent, perhaps, in south Anatolia (Helbaek 1959, Reed 1959).

Hitherto, a major problem has been to decide in which of these areas did farming first occur, and to learn if the development occurred independently in more than one. The cultural individuality of each region has often been stressed: clearly Jericho, Çatal Hüyük and Jarmo (or Ali Kosh) are not so closely related as to suggest that one is an offshoot of another. It has been observed too that both in the pre-farming Karim Shahir culture of the Zagros and in the Natufian culture of the Levant, signs of incipient cultivation of grain are found, seen in the silica gloss of flint sickle blades, and in the grinders and mortars common in sites in both regions. The cases argued for agricultural primacy have thus rested largely on the radiocarbon dates for early farming settlements. Amongst the earliest of these (Clark 1965 , a) may be quoted: $835^{\circ}$ B.C. (BM I06) for Pre-pottery Neolithic 'A' Jericho, 6890 B.C. and $645^{\circ}$ B.c. (DL-21, 4 and 9) for Ali Kosh-in the Ali Kosh phase, 6460 B.C. (K.IO06) for Level U at Tepe Guran, and 6I40 B.C. (P.782) for Level X at Çatal Hüyük.

However, the existence in the obsidian trade routes of ready-made channels for information would suggest that although culturally the Near East at this time 
can be divided into three major regions, technologically such a division might not be warranted. A way of life of settled mixed farming is of course based on many discoveries and advances: there was no brilliant, brief 'Neolithic Revolution', but a process of advance over several centuries or millennia. It now becomes improbable that major advances in the techniques of food production would be made in one region without the new knowledge, and in some cases the domesticates themselves, becoming available elsewhere. In our own day we are familiar with the rapid diffusion of technological ideas along our own, more efficient channels of information, often across cultural boundaries. Such diffusion does not necessarily imply significant alteration of populations, or of the material culture in fields not directly affected. The variations in material culture, therefore, are not necessarily a reliable indication of isolation or of disparity in farming competence.

As early as the Bus Mordeh phase at Ali Kosh, which the excavators equate with the pre-farming Karim Shahir culture, there is an efficient supply of obsidian along the Zagros, linking the regional sub-areas. These, already from the early period at Jarmo, show some cultural as well as an economic uniformity, perhaps in this case due to historical causes as much as to the large-scale cultural contact which by then has developed.

In the Levant, Jericho is linked via Tell Ramad, Ras Shamra, the Amouq and Mersin, to the Cappodocian sources. This inter-cultural intercourse, of which obsidian is the material trace, was undoubtedly an important factor working towards the various cultural similarities observed in the succeeding phase between the Amouq plain and Cappodocia, notably in the chipped stone industry (Bialor 1962, 104), and furthering the conformities between the Pre-pottery Neolithic ' $\mathrm{B}$ ' culture of Jericho and its contemporaries at Tell Ramad and Ras Shamra (Perrot I962, I 54).

There was apparently little contact between Cappodocia and Armenia or the Zagros at this early date, but Armenian obsidian reached the Levant at Upper Pre-pottery Neolithic Tell Ramad, perhaps via Bouqras, and even the Pre-pottery Neolithic 'B' culture at Beidha. Although similarities in the material culture are not notably evident between the Zagros area and the Levant, the early and rapid diffusion of farming innovations in each region, particularly from this period of contact a little before 6500 B.C., can no longer be regarded as independent phenomena.

On the contrary, the paths which already existed for cultural contact and the exchange of information, as indicated by the trade in obsidian, must already have served to communicate these momentous and yet basically simple technical advances. The 'Neolithic Revolution', rather than a great and unique event, was a complex phenomenon, and a co-operative one. Perhaps the most interesting aspect of the obsidian trade is the evidence which it affords for the widespread and early traffic in ideas and commodities, of which obsidian itself was by no means the most important. 


\section{BIBLIOGRAPHY}

Akкuş, M. F., 1962. 'The Geology of the area between Kütahya and Gediz', Bulletin of the Mineral Research and Exploration Institute of Turkey, vol. 88, 27.

Bialor, P. A., I962. 'The Chipped Stone Industry of Çatal Hüyük', Anatolian Studies, xII, 67.

Bordaz, J., 1964. 'Suberde Excavations', Anatolian Studies, xiv, 30.

Bostanci, E. Y., I959. 'Researches on the Mediterranean Coast of Anatolia, a new Palaeolithic Site at Beldibi near Antalya', Anatolia, IV, I29.

—-, I962. 'A New Upper Palaeolithic Facies at Belbaşi Rock Shelter on the Mediterranean Coast of Anatolia', Türk Tarih Kurumu Belleten, xxvı, 252.

Braidwood, R. J., I962. 'The Earliest Village Communities of South-western Asia Reconsidered', Atti dell VI. Congresso Internazionale delle Scienze Preistoriche e Proistoriche, I, Rome, I 5.

Bratdwood, R. J. and Braidwood, L. S., 1960. Excavations in the Plain of Antioch, I.

BraIdwood, R. J. and Howe, B., 1960. Prehistoric Investigations in Iraqi Kurdistan.

Burney, C. A., I964. 'Excavations at Yanik Tepe, Azerbaijan, I962', Iraq, xxv, 54.

CanN, J. R. and Renfrew, C., 1964. 'The Characterization of Obsidian and-its Application to the Mediterranean Region', $P P S, \mathrm{xxx}, \mathrm{II}$.

Cann, J. R., Dixon, J. E. and Renrrew, C. (forthcoming). 'Obsidian Analyses and the Obsidian 'Trade', D. Brothwell and E. S. Higgs (eds.), Science in Archaeology, and edition.

Cauvin, J., I962. 'Les Industries Lithiques du Tell de Byblos', L'Anthropologie, vol. 66, 488.

ChILde, V. G., 1954. New Light on the Most Ancient East.

ClARK, J. G. D., I952. Prehistoric Europe: the economic basis.

- - I965a. 'Radiocarbon Dating and the Spread of Farming', Antiquity, xxIx, 45.

$\longrightarrow, 1965$ b. 'Traffic in Stone Axe and Adze Blades', Economic History Review, xvII, $I$.

CuYler Young, C., I962. 'Sixth and Fifth Millennium Settlements in the Solduz Valley, Persia', Illustrated London News, 3 rd November, 1962, 707.

Dikaros, P., r953. Khirokitia.

-, I962. 'The Stone Age', The Swedish Cyprus Expedition, Iv, Part IA.

Esin, U. and Benedict, P., I963. 'Recent Developments in the Prehistory of Anatolia', Current Anthropology, vol. 4, No. 4, 339.

Garrod, D. A. E., I930. 'The Palaeolithic of Southern Kurdistan: excavations in the caves of Zarzi and Hazer Merd', Bulletin of the American School of Prehistoric Research, vol. 6, 8.

Garstang, J., I953. Prehistoric Mersin.

Ghirshmann, R., 1938. Fouilles de Sialk, I.

Gløb, P. V. and Bibby, T. G., 1960, 'A Forgotten Civilization of the Persian Gulf', Scientific American, October, I960, 62.

GoETZE, A., 1957. Kleinasien (Handbuch der Altertumswissenschaft III.I.3.3.I).

Hatzidakis, I., I912. 'Tylisos Minoiki', Ephemeris Archaeologiki, 1912, 217.

Helbaek, H., 1959. 'Domestication of Food Plants in the Old World', Science, vol. I30, No. 3372, 365.

Hole, F., 1958. 'A Reanalysis of Basal Tabbat al-Hammam, Syria', Syria, vol. 36, I49.

$\longrightarrow$, I962. 'Archaeological Survey and Excavation in Iran, 196r', Science, vol. I37, No. 3529, 524.

Hole, F., Flannery, K. and Neely, J., 1965. 'Early Agriculture and Husbandry in Deh Luran, Iran', Current Anthropology, vol. 6, 105.

JAHN, M., I956. 'Gab es in der Vorgeschichtlichen Zeit Bereits ein Handel?', Abhandlungen der sachsischen Akademie der Wissenschaften in Leipzig (Philologische-historische Klasse), vol. 48, Heft 2.

JanšaK, S., I935. Prähistorische Siedlungen mit Obsidiankultur in der Ostslowakei.

KenYon, K., I96r. 'Excavations at Jericho, 1957-8', Palestine Exploration Quarterly, r960-61, 88.

Kirkbride, D., 196r. 'The Excavation of a Neolithic Village at Seyl Aqlat, Beidha', Palestine Exploration Quarterly, 1960-6r, 136. 
Colin Renfrew, J. E. Dixon and J. R. Cann. Obsidian and Early Cultural Contact in the Near East

KöKTEN, I. K., r952. 'Anadolu' da prehistorik yerleşme yerlerinin dağilisi üzerine bir araştirma', Ankara Üniversitesi Dil ve Tarih-Coğrafya Fakültesi Dergisi, x, 167.

LAMB, W., 1936. 'Excavations at Kusura near Afyon Karahisar', Archaeologia, Lxxxvi, 43.

Liere, W. J. VAN and Contenson, H. DE, 1963. 'A Note on Five Early Neolithic Sites in Inland Syria', Annales Archaéologiques de Syrie, xIII, I82.

MallowaN, M. E. L., I965. 'The Mechanics of Ancient Trade in Western Asia', Iran, III, I.

Mallowan, M. E. L. and Rose, J. C., 1935. 'Excavations at Tell Arpachiyah i933', Iraq, Ir, 102.

MellaART, J., 1958. 'The Neolithic Obsidian Industry of Ilicapinar and its Relations', Istanbuler Mitteilungen, vol. 8, 82.

- , 1959. 'The Royal Treasure of Dorak', Illustrated London News, 28th November, 1959, 754.

—, I96ra. 'Excavations at Hacilar, Fourth preliminary report, I960', Anatolian Studies, xI, 39.

—, 1961b. 'Roots in the Soil', in S. Piggott (ed.), The Dawn of Civilization.

$\longrightarrow$, 1964. 'Excavations at Çatal Hüyük, I963', Anatolian Studies, xIv, 39.

Mortensen, P., 1964a. 'Early Village Farming Occupation, Tepe Guran, Luristan', Acta Archaeologica, XXXIv, I10.

- 1964b. 'Additional Remarks on the Chronology of Early Village Farming Communities in the Zagros Area', Sumer, xx, 28.

Naville, E., I922. 'Le Vase à Parfum de Byblos,' Syria, III, 29r.

OpPenheIm, A. L., I954. 'The Seafaring Merchants of Ur', Fournal of the American Oriental Society, vol. 74,6 .

Oswald, F., 1906. A Treatise on the Geology of Armenia (published at 'Iona', Beeston, Notts.).

Perrot, J., r962. 'Palestine-Syria-Cilicia', R. J. Braidwood and G. R. Woolley (eds.), Courses Towards Urban Life (Viking Fund Publications in Anthropology, 32).

Pumpelly, R., r9o8. Explorations in Turkestan: Prehistoric Civilizations of Anau, I.

Renfrew, C., Cann, J. R. and Dixon, J. E., 1965. 'Obsidian in the Aegean', Annual of the British School of Archaeology at Athens, vol. 60, 225.

ReED, C. A., I959. 'Animal Domestication in the Prehistoric Near East', Science, vol. 130, No. 3389, I629.

SCHAEFFER, C. A., I962. Ugaritica. Iv.

Smrth, W. S., 1965. Interconnections in the Ancient Near East.

Solecki, R. S., 1954. 'Shanidar Cave, a Palaeolithic Site in Northern Iraq', Annual Report of the Smithsonian Institution, I954, 389.

—, Ig63. 'Prehistory in Shanidar Valley, Northern Iraq', Science, vol. 139, No. 3551, 179.

Stekelis, M. and YizRaely, T., 1963. 'Excavations at Nahal Oran', Israel Exploration fournal, vol. I3, $\mathrm{I}$.

Sтоск, H., 1963. 'Der Hyksos Chian in Boğazköy', Mitteilungen der deutschen Orient-gesellschaft zu Berlin, vol. 94, 7.4:

TOBLER, A. J., 1950. Excavations at Tepe Gawra, II.

Todd, I. A., 1965. 'Central Anatolian Survey', Anatolian Studies, xv, I3.

Todn, I. A. and Pasquaré, G., 1965. 'The Chipped Stone Industry of Avla Dağ', Anatolian Studies, $\mathrm{xv}, 95$.

Virolleaud, C., I922. 'Découverte à Byblos d'un hypogée de la douzième dynastie Égyptienne', Syria, III, 273.

Wainwright, G. A., 1927. 'Obsidian', Ancient Egypt, 1927, Part 3.

Woolley, L. W., I955. Alalakh: Tell Atchana.

Zeuner, F. E., 1963. A History of Domesticated Animals. 


\section{APPENDIX A. QUANTITIES OF OBSIDIAN FOUND}

The column headed ' $\%$ Green' gives a figure for the percentage of the total obsidian which is green in colour in transmitted light. This probably derives from the group $4 \mathrm{c}$ source at Nemrut Dağ on Lake Van. 'Total' refers to the complete chipped stone assemblage, including flint. The locations of the sites are shown on fig. $I$.

I. Tell Shemshara (Mortensen 1964b; information kindly supplied by $\mathrm{Mr}$ Peder Mortensen). The sample of 909 chipped stone pieces available for counting is only a part of the assemblage recovered. The figures for the green obsidian are derived from a smaller sample of 485 obsidian fragments.

\begin{tabular}{c|c|c|c|c|c|c}
\hline Level & Obsidian & Total & $\%$ Obsidian & Green & $\%$ Green & Period \\
\hline 9 & I4 & I6 & 88 & 0 & $\circ$ & c. 5000 B.C. \\
I0 & 462 & 514 & 90 & 61 & 23 & \\
II & 99 & I3I & 78 & 8 & I4 & \\
I2 & 44 & 49 & 89 & I & $(50)$ & \\
I3 & I4 & I7 & 83 & 9 & 50 & \\
I4 & 60 & 73 & 82 & 13 & 30 & \\
I5 & 34 & 37 & 92 & I & (100) & c. 5600 B.c. \\
I6 & 26 & 32 & 81 & 6 & 50 & c. \\
\hline
\end{tabular}

2. Farmo (Braidwood and Howe 1960; information kindly supplied by Dr Frank Hole).

\begin{tabular}{c|c|c|c|c}
\hline Level & Obsidian & Total & $\%$ Obsidian & Period \\
\hline Jarmo II & $\begin{array}{c}33,106 \\
6,105\end{array}$ & $\begin{array}{c}72,069 \\
21,170\end{array}$ & $\begin{array}{c}45 \\
\text { Jarmo I }\end{array}$ & $\begin{array}{c}\text { c. } 6500 \text { to } 6000 \text { B.C. } \\
\text { c. } 7000 \text { to 6500 B.c. }\end{array}$ \\
\hline
\end{tabular}

3. Tepe Guran (Mortensen 1964a; information kindly supplied by Mr Peder Mortensen).

\begin{tabular}{|c|c|c|c|c|c|c|}
\hline Level & Obsidian & Total & $\%$ Obsidian & Green & $\%$ Green & Period \\
\hline D & 9 & c. 130 & 7 & 4 & 44 & c. 5000 B.C. \\
\hline $\mathrm{E}$ & 12 & c. 150 & 8 & 6 & 50 & \\
\hline $\mathrm{F}$ & 5 & c. 170 & 3 & 0 & (0) & \\
\hline $\mathrm{G}$ & 3 & c. 75 & 4 & 0 & (o) & \\
\hline $\mathrm{H}$ & IO & c. IIO & 9 & 9 & 90 & \\
\hline $\mathrm{J}$ & 4 & c. 40 & IO & 2 & (50) & \\
\hline $\mathrm{K}$ & 7 & c. 65 & II & 6 & $(85)$ & \\
\hline $\mathrm{L}$ & 5 & c. 45 & I I & 3 & $(60)$ & \\
\hline M & 4 & c. 40 & IO & o & (o) & \\
\hline $\mathrm{N}$ & 4 & c. 20 & 20 & 4 & $(100)$ & \\
\hline $\mathrm{O}$ & 7 & c. 16 & 45 & 4 & $(60)$ & \\
\hline$P$ & 8 & c. 35 & 22 & 2 & $(25)$ & \\
\hline Q & 3 & c. 45 & 7 & $\mathbf{I}$ & (33) & \\
\hline $\mathbf{R}$ & 0 & n.r. & $\circ$ & - & - & \\
\hline $\mathrm{S}$ & $\mathbf{I}$ & c. 17 & 6 & 0 & (o) & c. 6300 B.C. \\
\hline $\mathrm{T}$ & 36 & $c .80$ & 46 & I & 3 & \\
\hline $\mathrm{U}$ & 0 & n.r. & 0 & - & - & \\
\hline V & 2 & c. 100 & 2 & 2 & $(100)$ & c. 6500 B.C. \\
\hline
\end{tabular}


Colin Renfrew, J. E. Dixon and J. R. Cann. Obsidian and Early Cultural Contact in the Near East 4. Sarab (Mortensen I964a, I21; information kindly supplied by Dr Frank Hole).

\begin{tabular}{c|c|c|c|c}
\hline Level & Obsidian & Total & $\%$ Obsidian & Period \\
\hline Sarab IC & 723 & 40,864 & $\mathrm{I} .8$ & c. 5900 B.C. \\
\hline
\end{tabular}

5. Deh Luran region (Hole 1962; information kindly supplied by Dr Frank Hole).

\begin{tabular}{|c|c|c|c|c|c|c|}
\hline Level & Obsidian & Total & $\%$ Obsidian & Green & $\%$ Green & Period \\
\hline $\begin{array}{ll}\text { Bayat .. } & \text {. } \\
\text { Mehmeh } & \ldots \\
\text { Khazineh } & \ldots \\
\text { Sabz . } & \ldots \\
\text { Mohammad Jaffar } \\
\text { Ali Kosh } \\
\text { Bus Mordeh }\end{array}$ & $\begin{array}{r}6 \\
3 \\
0 \\
0 \\
417 \\
474 \\
347\end{array}$ & $\begin{array}{r}1,267 \\
662 \\
820 \\
\mathrm{I}, 873 \\
23,934 \\
23,231 \\
40,114\end{array}$ & $\begin{array}{l}0.5 \\
0.5 \\
0.0 \\
0.0 \\
1.7 \\
2.1 \\
0.9\end{array}$ & $\begin{array}{c}6 \\
3 \\
- \\
- \\
251 \\
55^{8} \\
200\end{array}$ & $\begin{array}{c}(100) \\
(100) \\
- \\
- \\
65 \\
95 \\
99\end{array}$ & $\begin{array}{l}\text { Late Ubaid, } c .4000 \text { B.c. } \\
\text { Early Ubaid } \\
\text { Halaf, } c .5300 \text { B.C. } \\
\text { Hassuna/Susa } \\
\text { Jarmo II/U. Guran } \\
\text { Jarmo I/L. Guran } \\
\text { Earlier aceramic, before } \\
\text { 7000 B.C. }\end{array}$ \\
\hline
\end{tabular}

6. Bouqras (van Liere and de Contenson 1963; information kindly sent by M. Henri de Contenson). Figures based on finds of the 1965 season.

\begin{tabular}{c|c|c|c|l}
\hline Level & Obsidian & Total & $\%$ Obsidian & \multicolumn{1}{|c}{ Period } \\
\hline III & I5 & 577 & $27 \cdot 9$ & Ceramic layer \\
II & 295 & I, I55 & $25 \cdot 7$ & Aceramic layer \\
I & I73 & 535 & $32 \cdot 3$ & Aceramic (Jarmo period) \\
\hline
\end{tabular}

In a sample of 179 pieces from the aceramic Neolithic levels, green obsidian forms 39 per cent.

7. Çatal Hüyük (Mellaart 1964, information kindly supplied by Mr Peder Mortensen. The figures apply to artifacts only, excluding waste).

\begin{tabular}{l|c|c|c|c}
\hline Level & Obsidian & Total & $\%$ Obsidian & Period \\
\cline { 2 - 4 } II & 485 & 504 & 96 & c. 5600 B.c. \\
III & 742 & 766 & 97 & \\
IV & I50 & 154 & 97 & \\
V & 474 & 492 & 96 & \\
VI A-B & 560 & 612 & 91 & \\
VII & 184 & 204 & 90 & \\
VIII & 20 & 22 & 91 & \\
IX & 542 & 47 & 89 & \multirow{2}{*}{ C. 6200 B.c. } \\
X & 36 & $4 I$ & 88 & \\
\hline
\end{tabular}


8. Mersin (Garstang 1953. The last three figures are from the note by W. C. Brice, ibid. I25).

\begin{tabular}{|c|c|c|c|c|}
\hline Level & Obsidian & Total & $\%$ Obsidian & Period \\
\hline $\begin{array}{ll}\text { XX } & \cdots \\
\text { XXI } \cdots & \cdots \\
\text { XXII } & \cdots \\
\text { XXIII } & \cdots \\
\text { XXIV } & \cdots \\
\text { XXV } \ldots & \cdots \\
\text { XXVI } & \cdots \\
\text {-XXVII } & \cdots \\
\text { XX-XVI } & \cdots \\
\text { XXIV-XXI } & \ldots \\
\text { XXVIII-XXV }\end{array}$ & $\begin{array}{r}70 \\
37 \\
86 \\
\text { II } 7 \\
213 \\
85 \\
37 \\
72 \\
\text { n.r. } \\
\text { n.r. } \\
\text { n.r. }\end{array}$ & $\begin{array}{r}98 \\
48 \\
112 \\
156 \\
248 \\
112 \\
53 \\
79 \\
631 \\
\text { I, I } 19 \\
1,214\end{array}$ & $\begin{array}{l}71 \\
77 \\
77 \\
75 \\
86 \\
76 \\
70 \\
91 \\
84 \\
77 \\
87\end{array}$ & $\begin{array}{l}\text { Early Chalcolithic, } c .5300 \text { B.C. } \\
\qquad ", \\
\text { Proto-Chalcolithic } \\
\text { Upper Neolithic } \\
\text { Basal Neolithic, c. } 6000 \text { B.c. } \\
\text { Middle Chalcolithic } \\
\text { Early Chalcolithic } \\
\text { Neolithic }\end{array}$ \\
\hline
\end{tabular}

9. Basal Tabbat al-Hammam (Hole 1959, I60). Obsidian apparently formed about 5 per cent of the total chipped stone assemblage at this site, datable to the Amouq A-B phases in the early 6th millennium B.C.

ro. Tell al-fudaidah (Braidwood and Braidwood 1960; from the Appendix by Mrs J. Crowfoot Payne, ibid. 539).

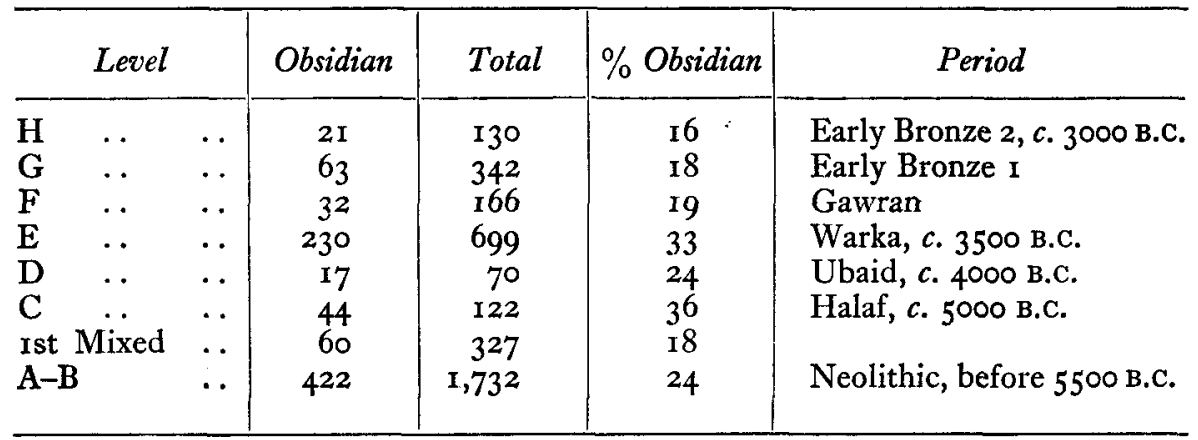

II. Byblos (Cauvin 1962; from information kindly supplied by M. Jacques Cauvin). In the Late Neolithic period, seventeen in a sample of forty-four pieces of obsidian, 39 per cent, were green in transmitted light.

\begin{tabular}{|c|c|c|c|c|c|}
\hline Level & & Obsidian & Total & $\%$ Obsidian & Period \\
\hline $\begin{array}{l}\text { Eneolithic } \\
\text { Late Neolithic . } \\
\text { Middle Neolithic } \\
\text { Early Neolithic. . }\end{array}$ & $\begin{array}{l}\cdots \\
\cdots \\
\cdots \\
\cdots\end{array}$ & $\begin{array}{r}55 \\
55 \\
8 \\
18\end{array}$ & $\begin{array}{r}c .8 \mathrm{I} 5 \\
1,425 \\
502 \\
2,186\end{array}$ & $\begin{array}{c}c .7 \\
4 \\
I .6 \\
0.8\end{array}$ & $\begin{array}{l}\text { c. } 3300 \text { B.c. } \\
\text { c. } 4000 \text { B.c. } \\
\text { Before } 5000 \text { B.c. }\end{array}$ \\
\hline
\end{tabular}


12. Tell Ramad (van Liere and de Contenson 1963; from information kindly supplied by $\mathbf{M}$. Henri de Contenson). The figures are for sifted material recovered from Square $\mathrm{M}_{4}$ during the I 965 excavation season.

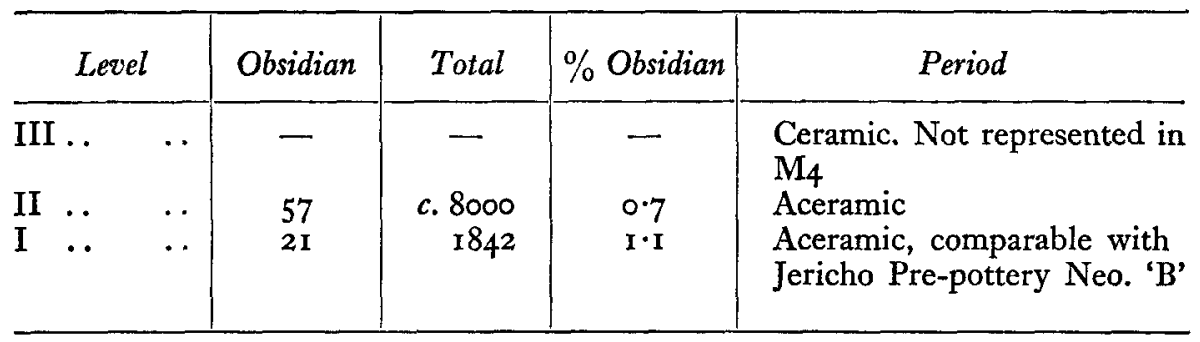

13. Nahal Oren (Stekelis and Yizraely 1963). There is no mention of obsidian in the Natufian levels. In structure Io of Stratum II (Pre-pottery Neolithic 'A'), obsidian blades form I per cent of the total lithic assemblage (ibid. fig. 5). There is less obsidian in the succeeding Stratum I.

14. Fericho (Kenyon 196r; information kindly supplied by Mrs J. Crowfoot Payne). No green obsidian has been recorded from Jericho. The following figures are based on a study of about twothirds of the excavated material.

\begin{tabular}{|c|c|c|c|c|}
\hline Level & Obsidian & Total & $\%$ Obsidian & Period \\
\hline $\begin{array}{l}\text { Early Bronze Age } \\
\text { Pottery Neolithic } \\
\text { Pre-pottery Neolithic 'B' } \\
\text { Pre-pottery Neolithic 'A' } \\
\text { Proto-Neolithic } \\
\text { Natufian .. }\end{array}$ & $\begin{array}{r}2 \\
0 \\
60 \\
344 \\
0 \\
0\end{array}$ & $\begin{array}{r}599 \\
419 \\
4,944 \\
\mathrm{I}, 884 \\
83 \\
457\end{array}$ & $\begin{array}{l}0 \cdot 3 \\
0 \cdot 0 \\
1 \cdot 2 \\
2 \cdot 9 \\
0 \cdot 0 \\
0 \cdot 0\end{array}$ & $\begin{array}{l}\text { c. } 3000 \text { B.c. } \\
\text { c. } 5000 \text { B.c. } \\
\text { Early } 7 \text { th millennium B.c. } \\
\text { 8th millennium B.C. } \\
\text { Before } 8000 \text { B.C. } \\
\text { gth millennium B.c. }\end{array}$ \\
\hline
\end{tabular}

Table I. The Provenances of the Obsidian analysed and Table II. The Trace-element Composition of the Obsidians analysed on following pages. 


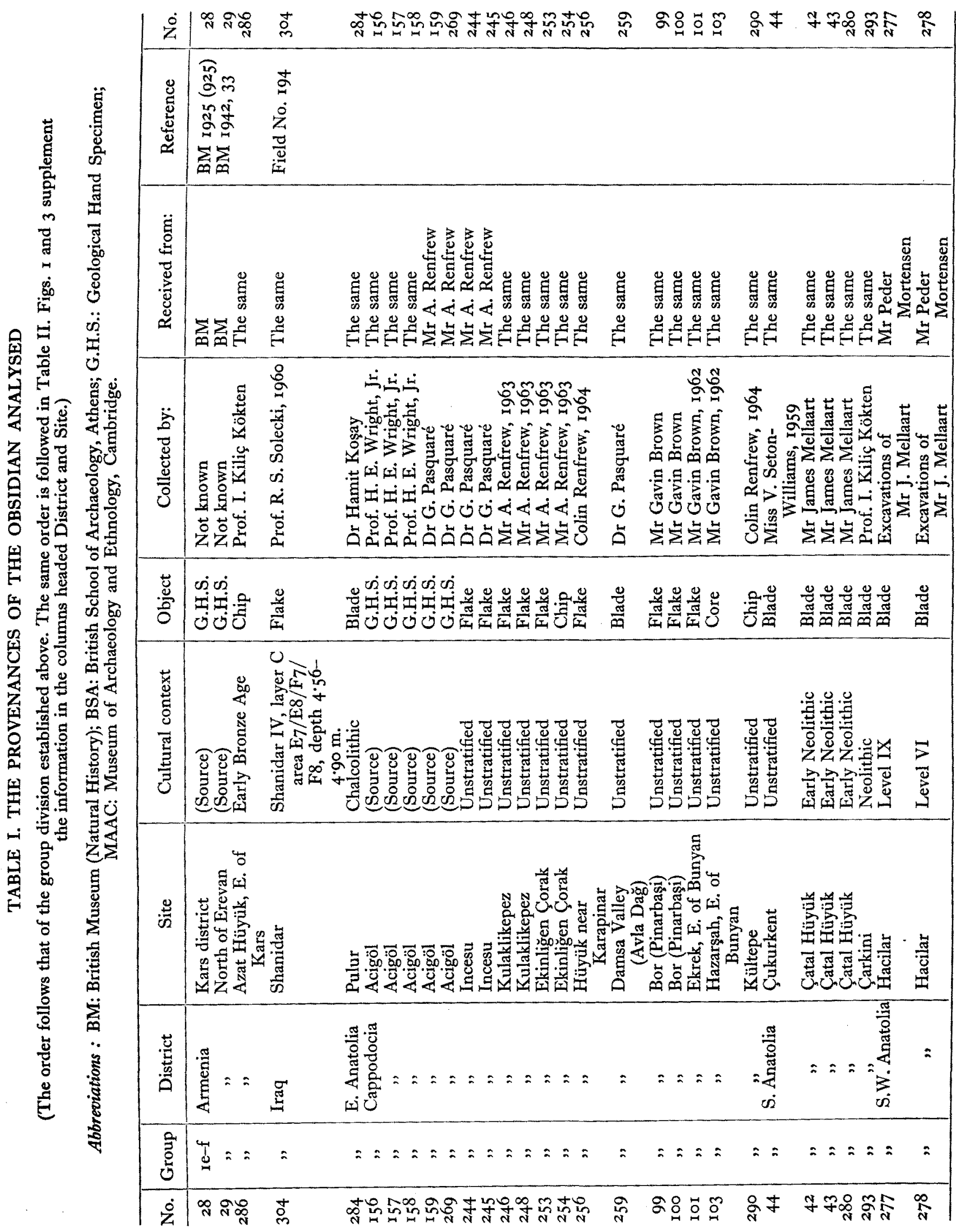




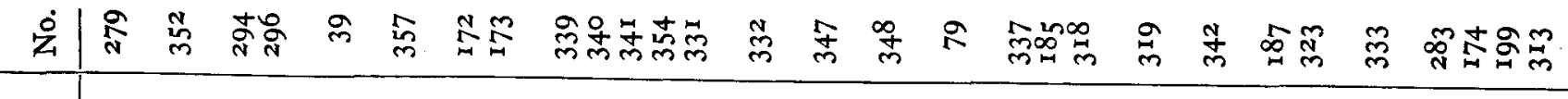

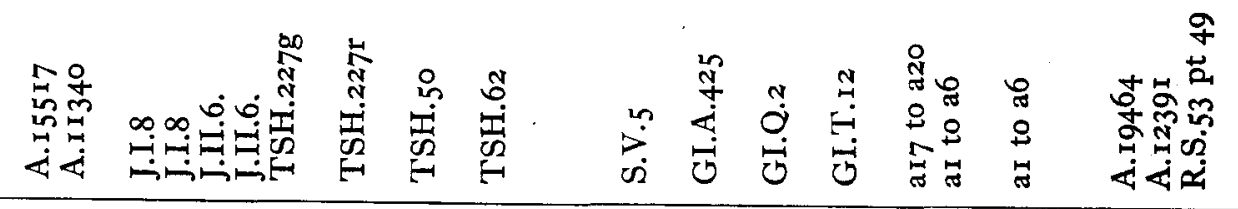

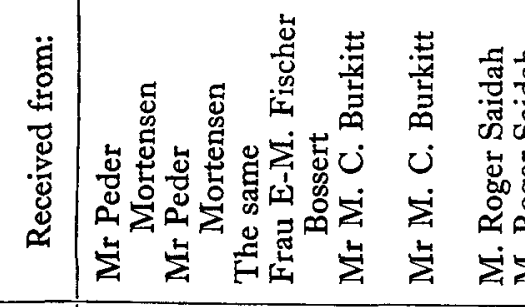

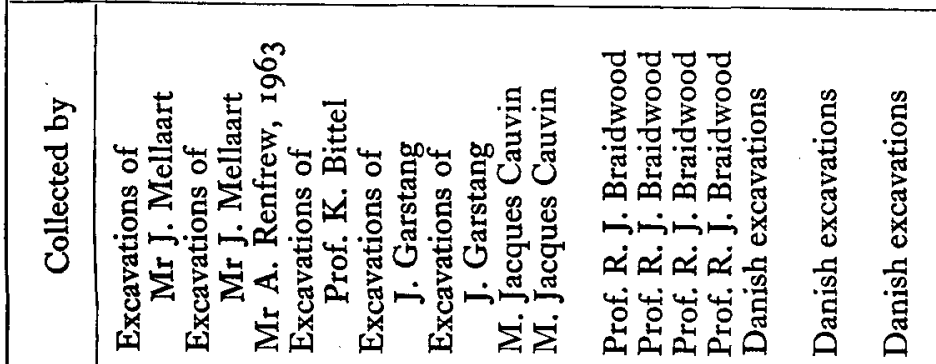

壱

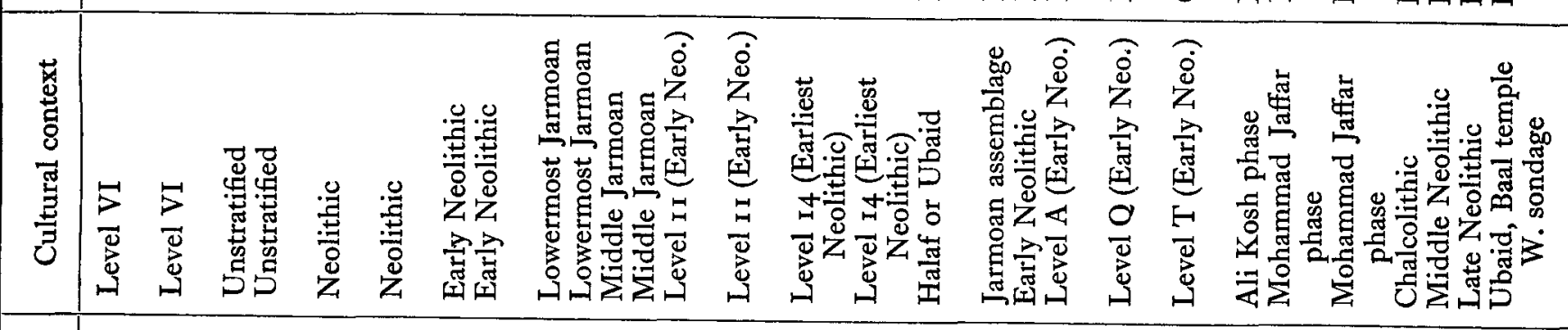

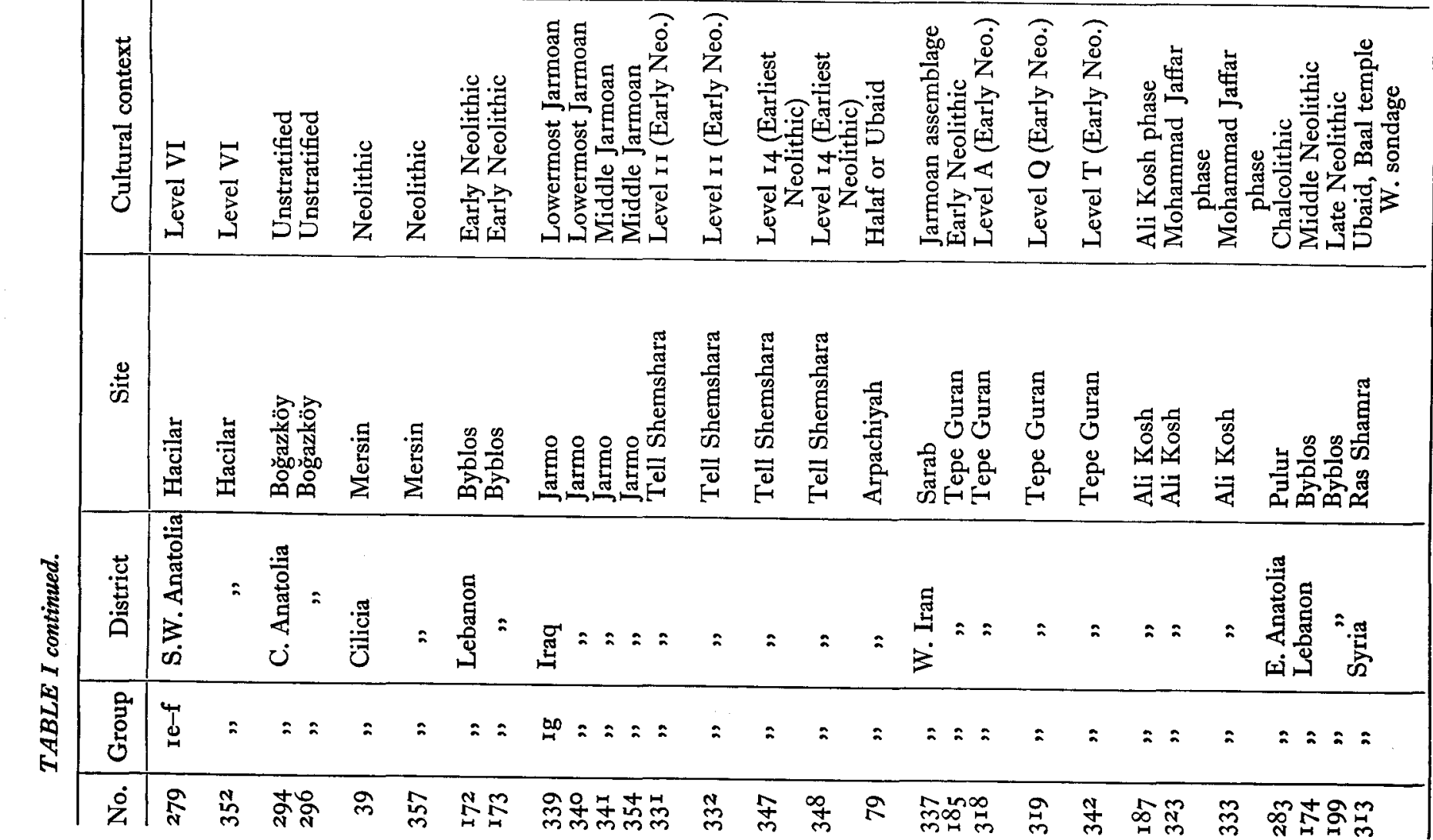

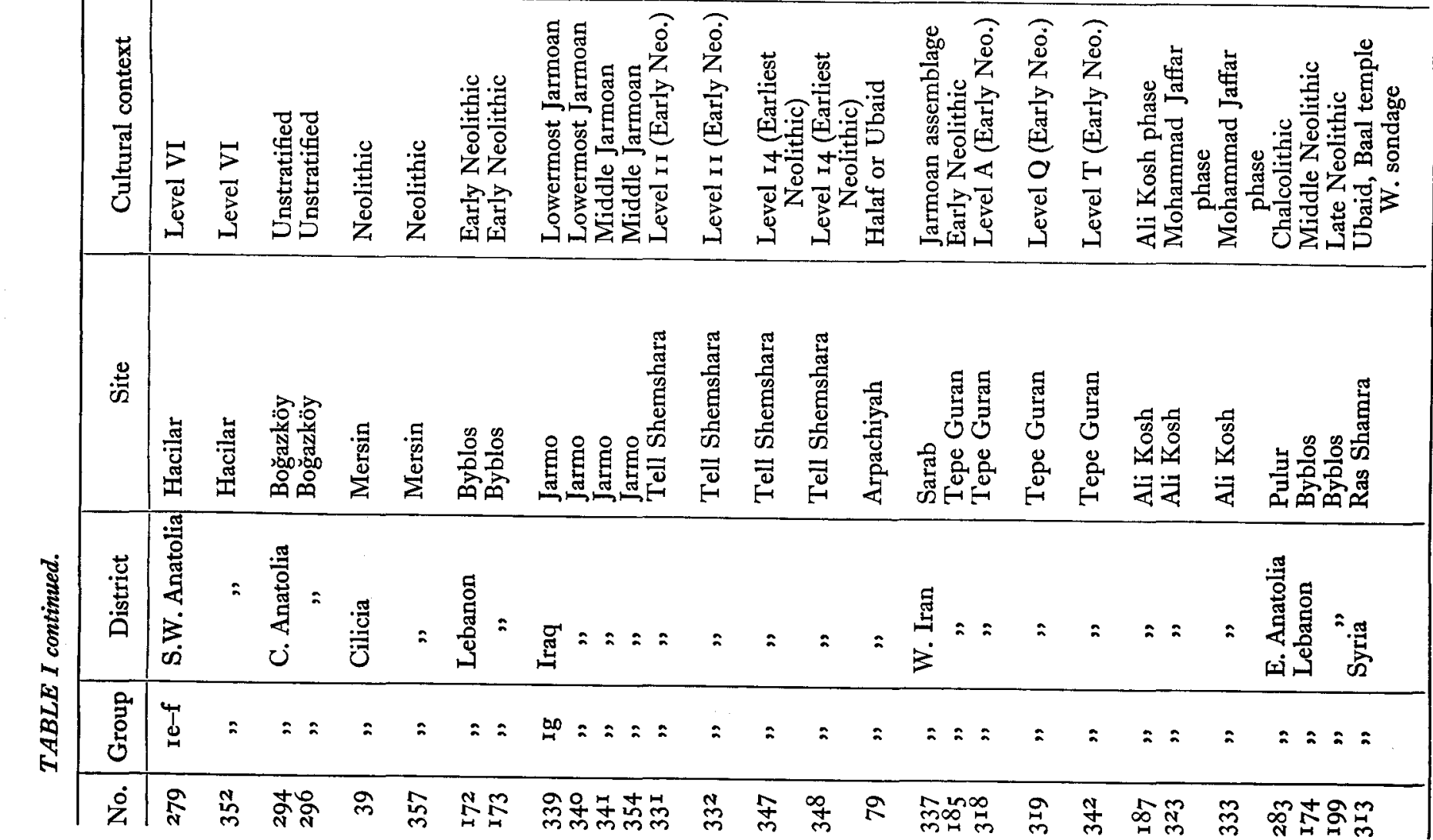

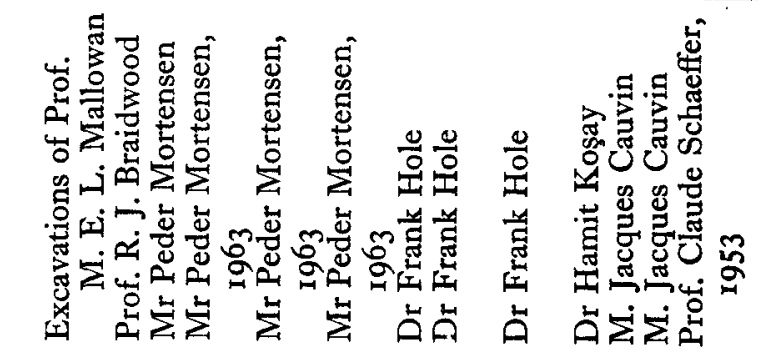

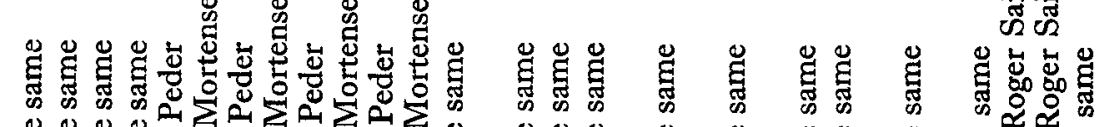

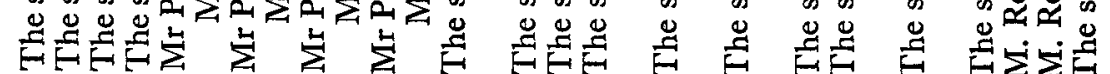




\begin{tabular}{|c|c|c|c|c|c|c|c|c|c|c|c|}
\hline 完 & $\underset{m}{ \pm}$ & $\stackrel{\mathscr{6}}{\circ}$ & 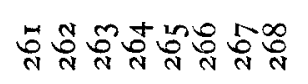 & 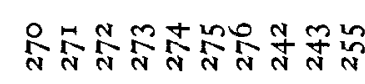 & $\stackrel{n}{n}$ & న్ & $\underset{N}{\infty}$ & $\stackrel{\infty}{\infty}$ & 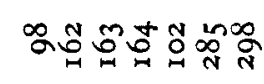 & ฉू & $\stackrel{8}{\circ}$ \\
\hline 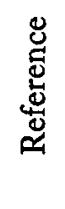 & 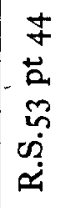 & & & & & & & & & & \\
\hline 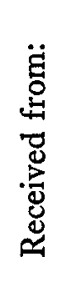 & 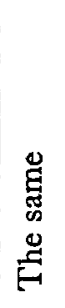 & 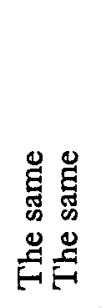 & 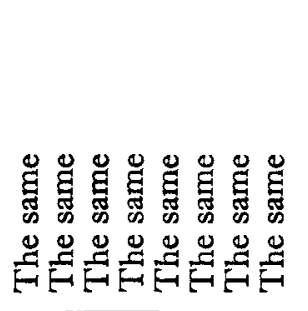 & 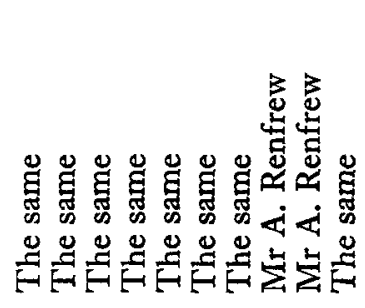 & 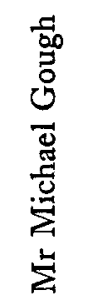 & 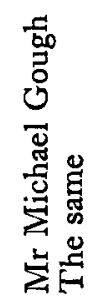 & 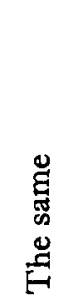 & 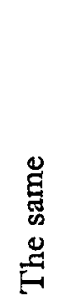 & 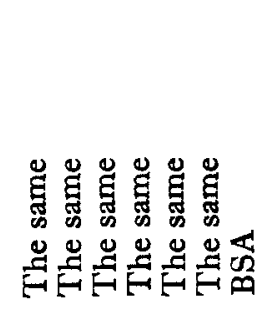 & $\underset{\aleph}{\mathscr{A}}$ & 蛋 \\
\hline 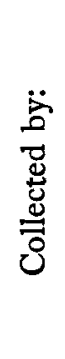 & 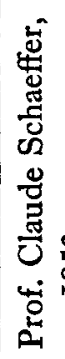 & 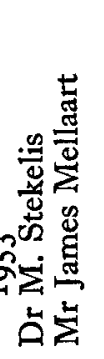 & 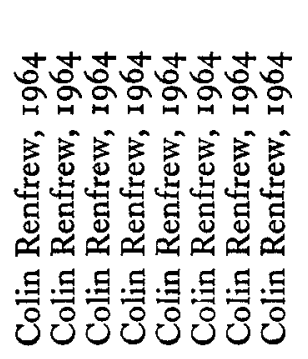 & 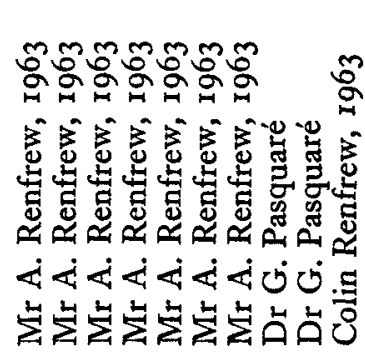 & 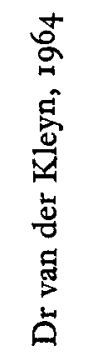 & 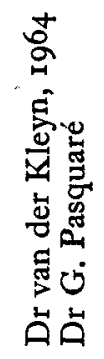 & 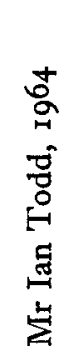 & 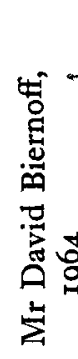 & 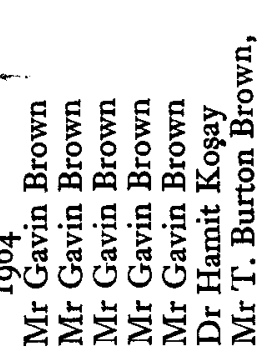 & 焉 & 竞 \\
\hline 蒡 & $\frac{\tilde{g}}{\not{m}}$ & 亲营 & فن & 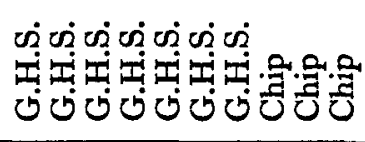 & $\frac{\ddot{g}}{m}$ & 营 & $\frac{\mathscr{g}}{\tilde{m}}$ & $\frac{0}{\frac{9}{9}}$ & 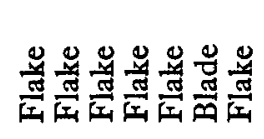 & $\frac{\mathscr{y}}{\sqrt[3]{x}}$ & $\frac{y}{\mathbb{3}}$ \\
\hline 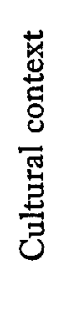 & 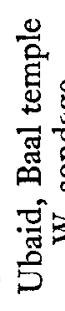 & 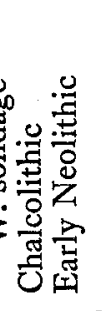 & 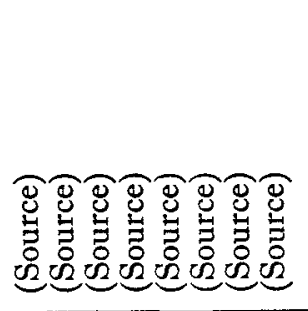 & 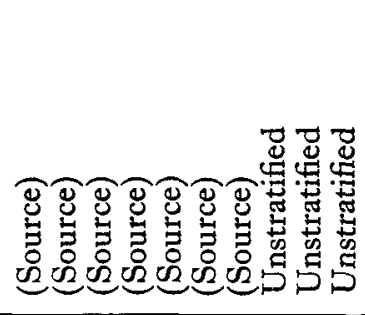 & 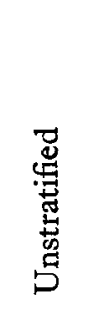 & 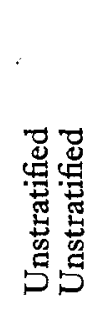 & 壳 & 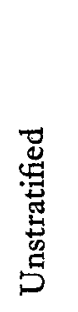 & 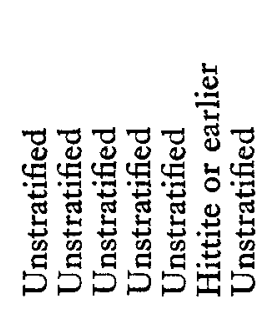 & 营 & 总 \\
\hline 壳 & 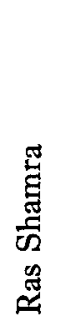 & 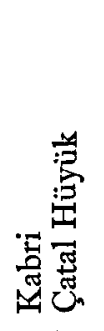 & 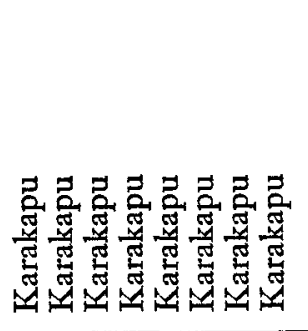 & 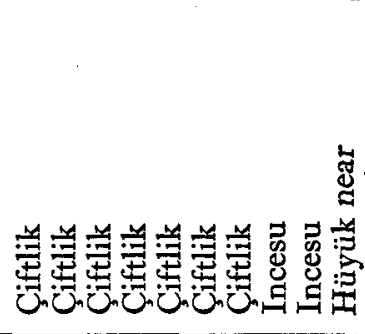 & 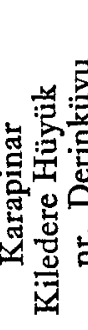 & 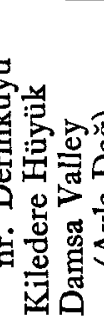 & 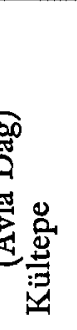 & 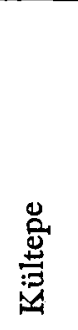 & 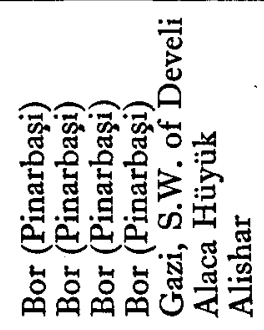 & 莺 & 莺 \\
\hline . & 营 & 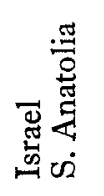 & $\begin{array}{l}\frac{\pi}{0} \\
\frac{0}{0} \\
\frac{0}{0} \\
\frac{0}{2}\end{array}==2==2=$ & 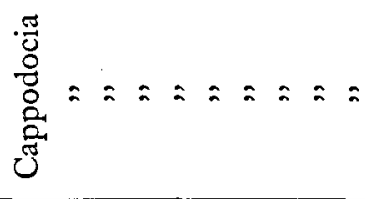 & $=$ & $=2$ & $\approx$ & $=$ & 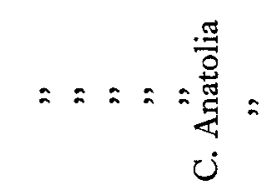 & $=$ & $=$ \\
\hline 害 & bo & $=2$ & $\underline{F}=2=2=2$ & $\frac{0}{N}=z=z=z=0$ & $=$ & $==$ & $=$ & $=$ & $=z=2=2$ & $=$ & $=$ \\
\hline$\dot{2}$ & 志 & 哭子 & 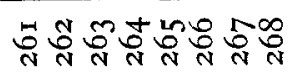 & 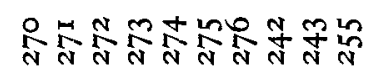 & กิ & Џ్ำ & $\underset{N}{\infty}$ & $\stackrel{\text { \& }}{\infty}$ & 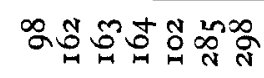 & ฉ্̀ & $\stackrel{\text { : }}{\circ}$ \\
\hline
\end{tabular}




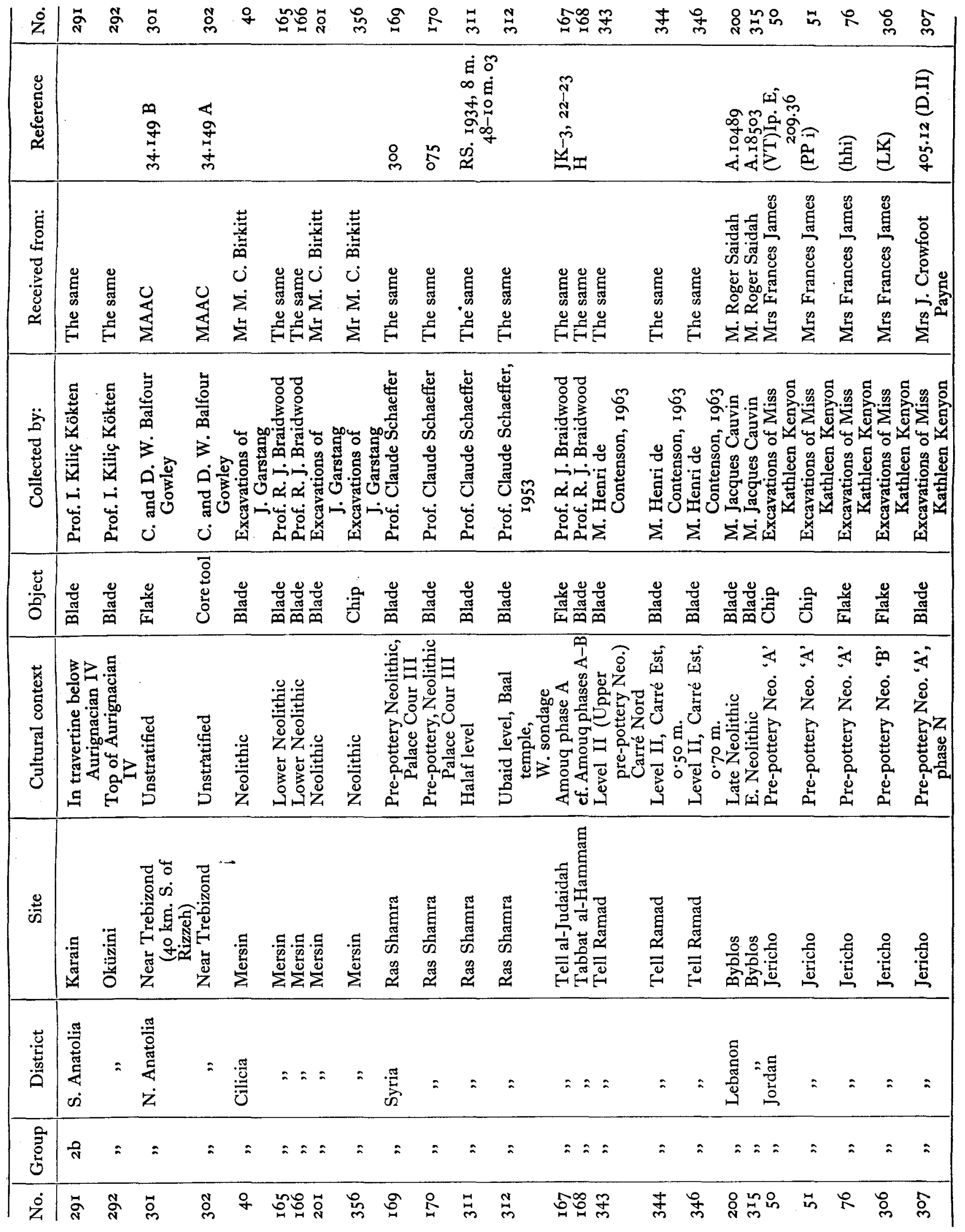




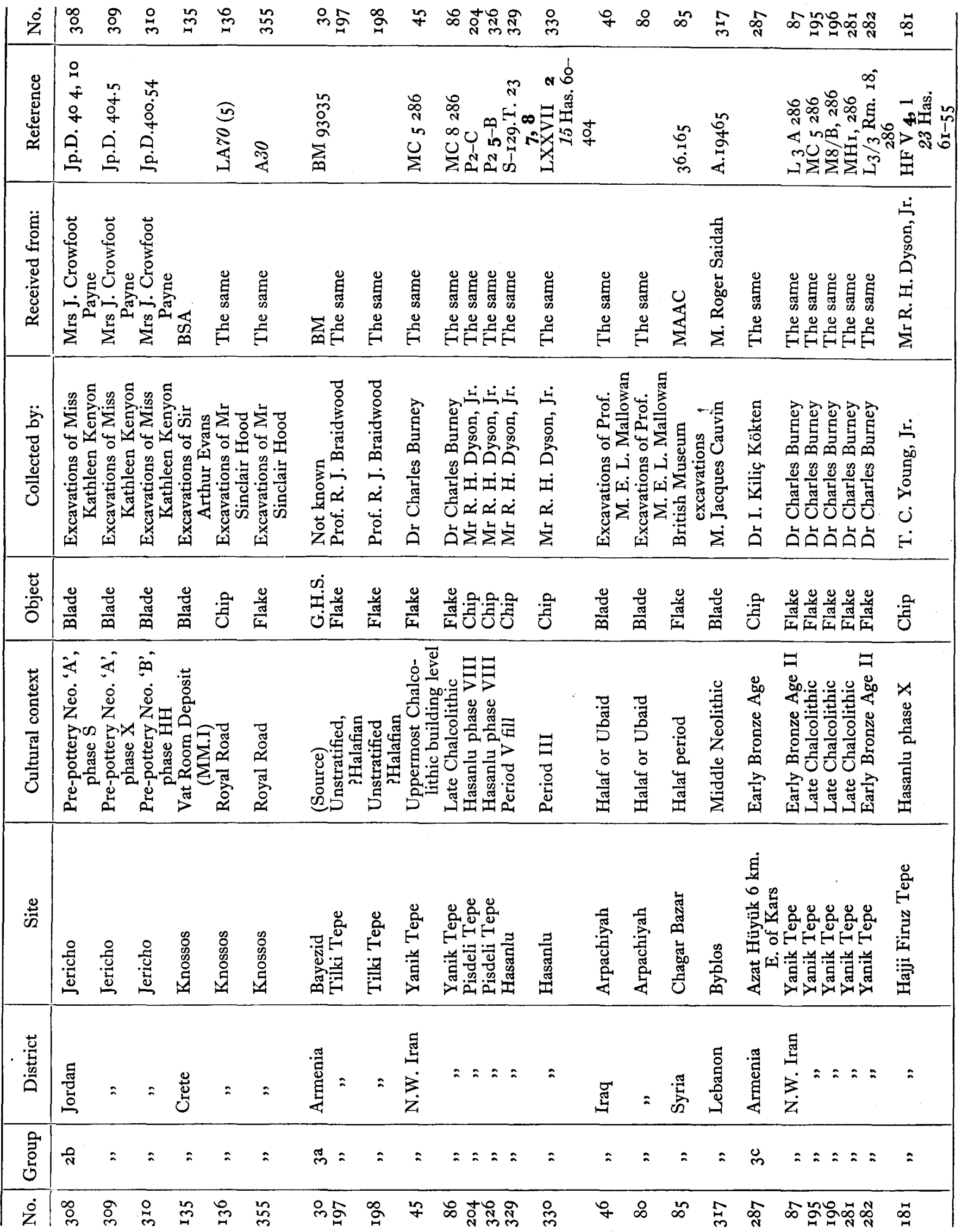




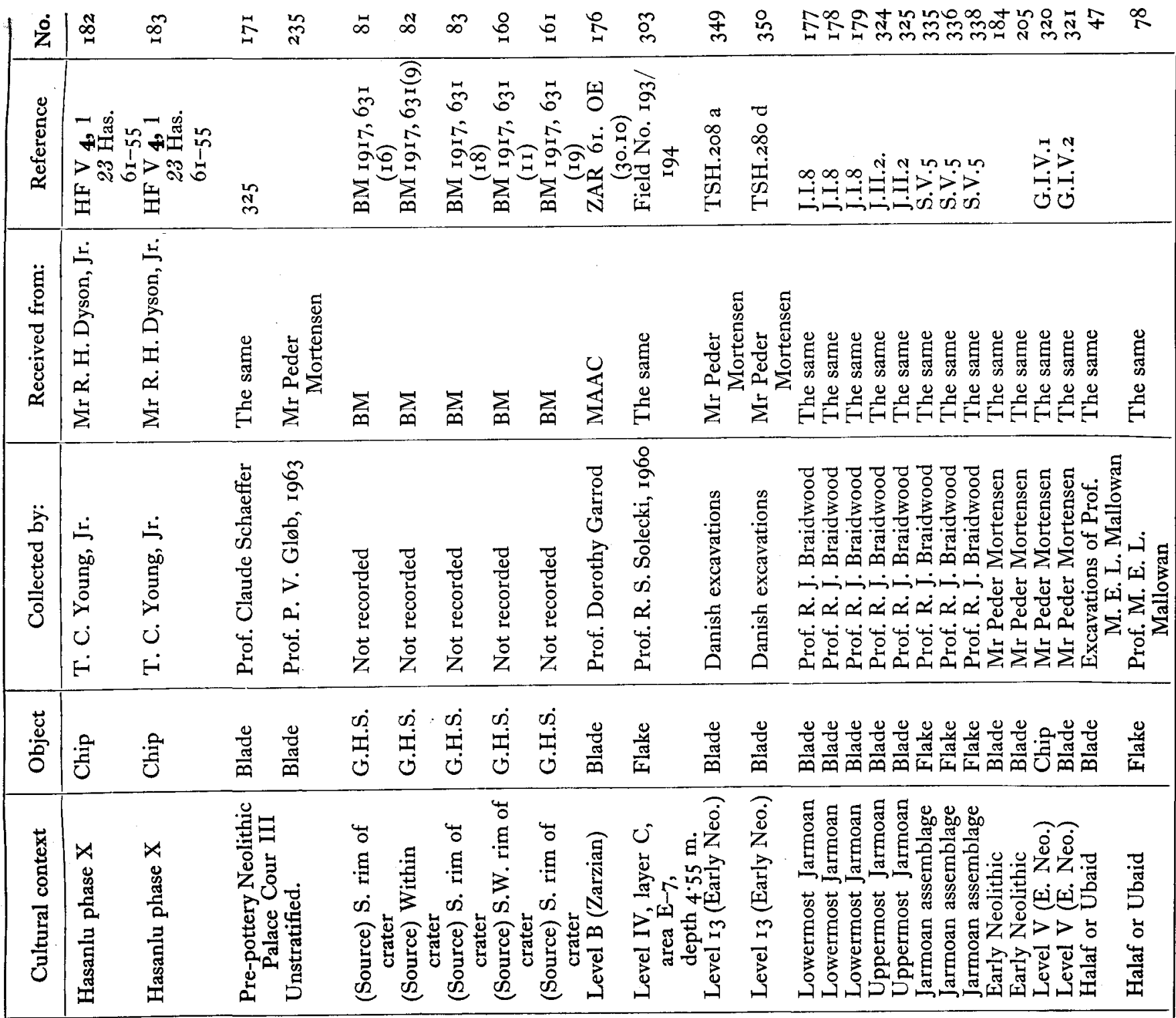

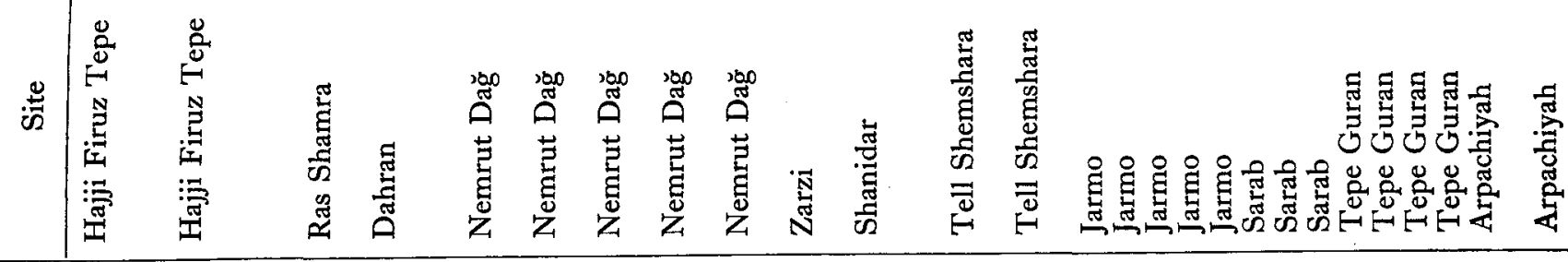

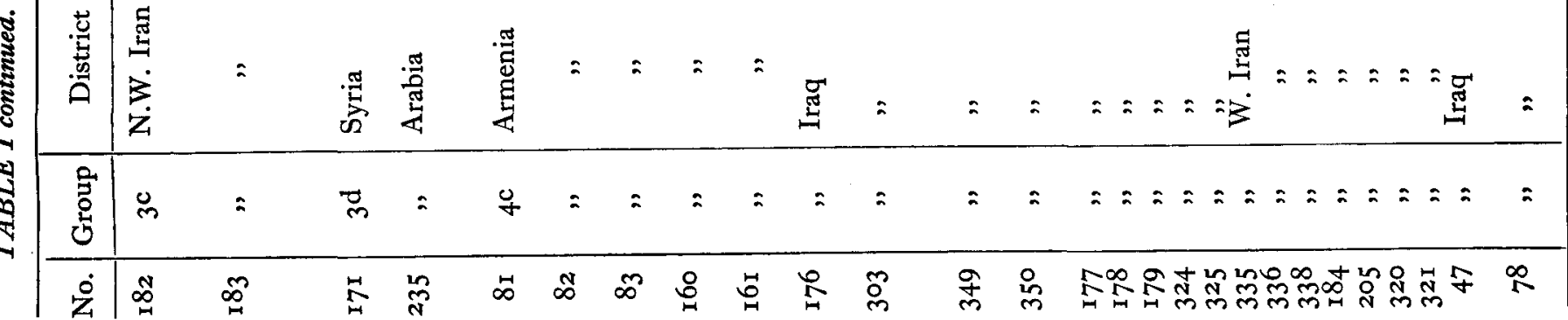


|

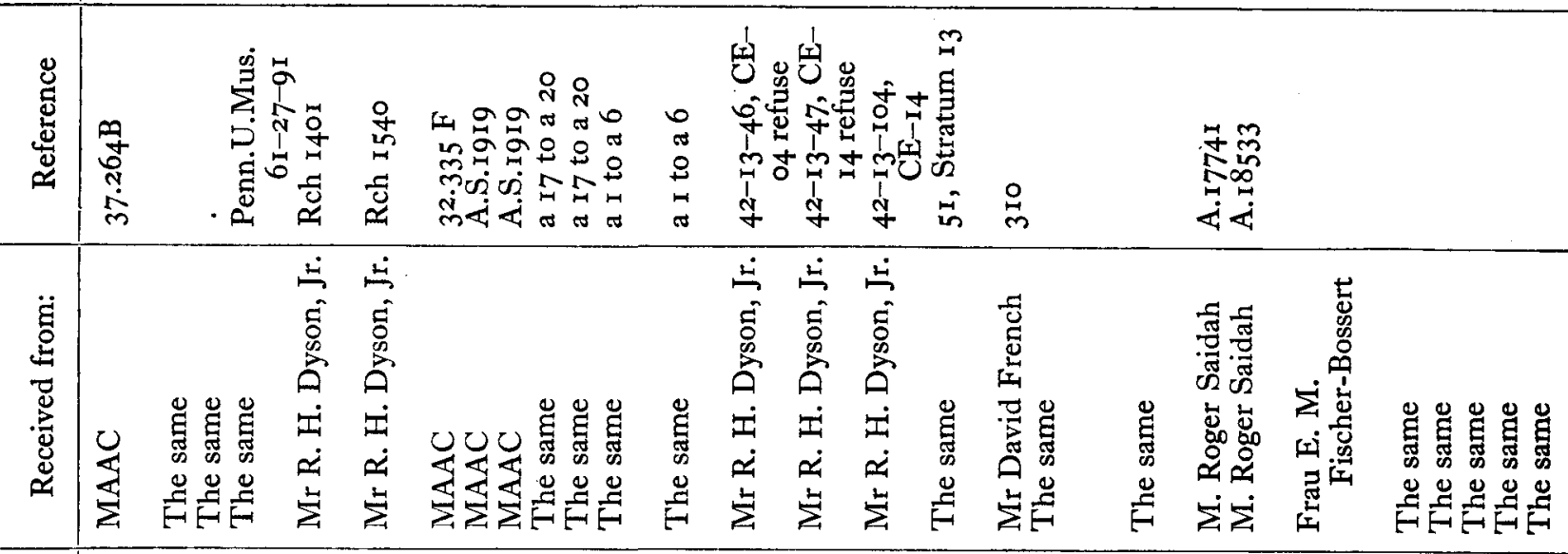

\begin{tabular}{|c|c|c|c|c|c|c|}
\hline & 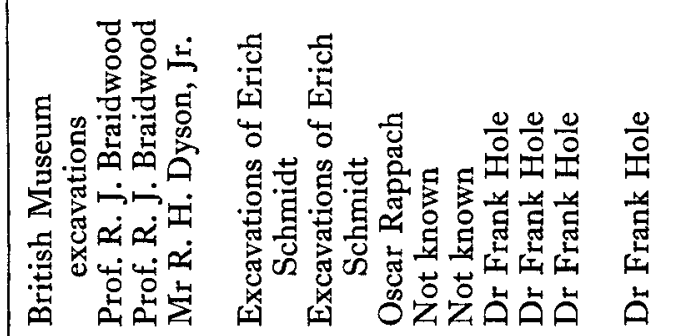 & 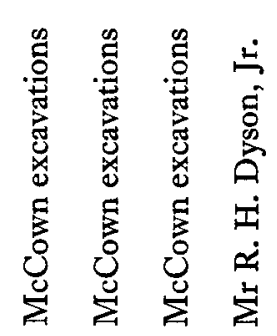 & 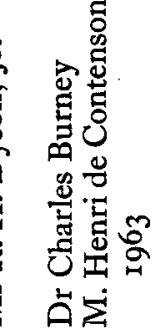 & 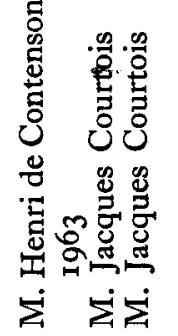 & 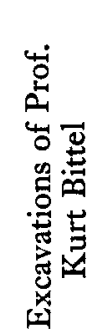 & 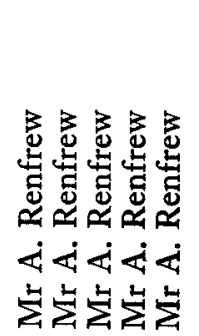 \\
\hline
\end{tabular}

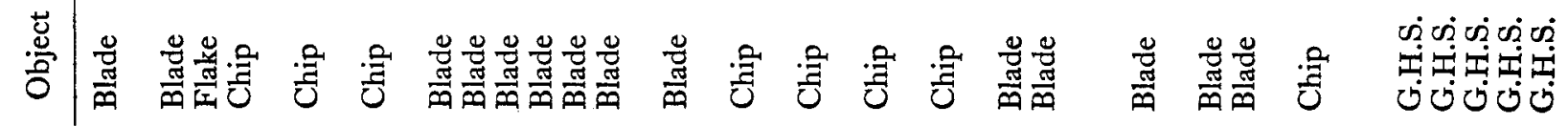

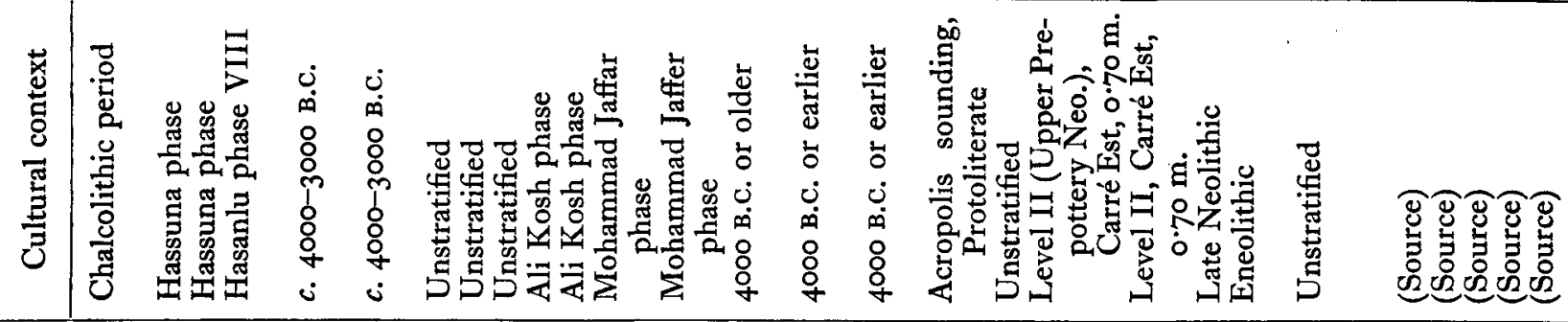

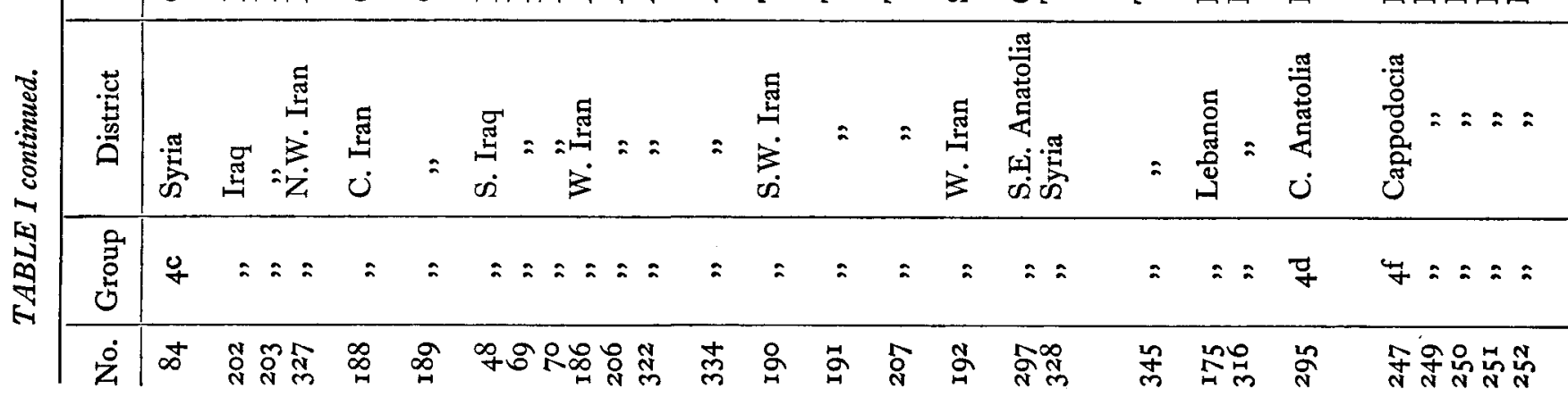



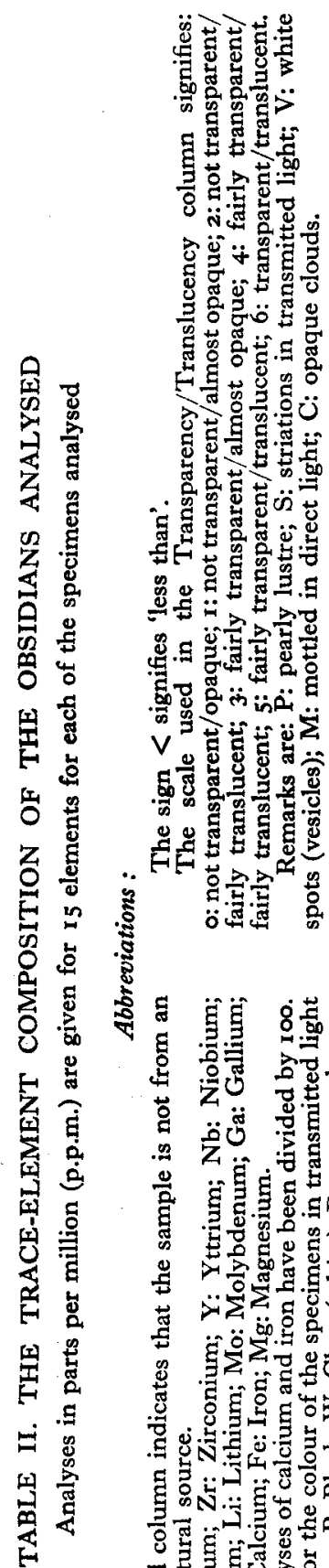

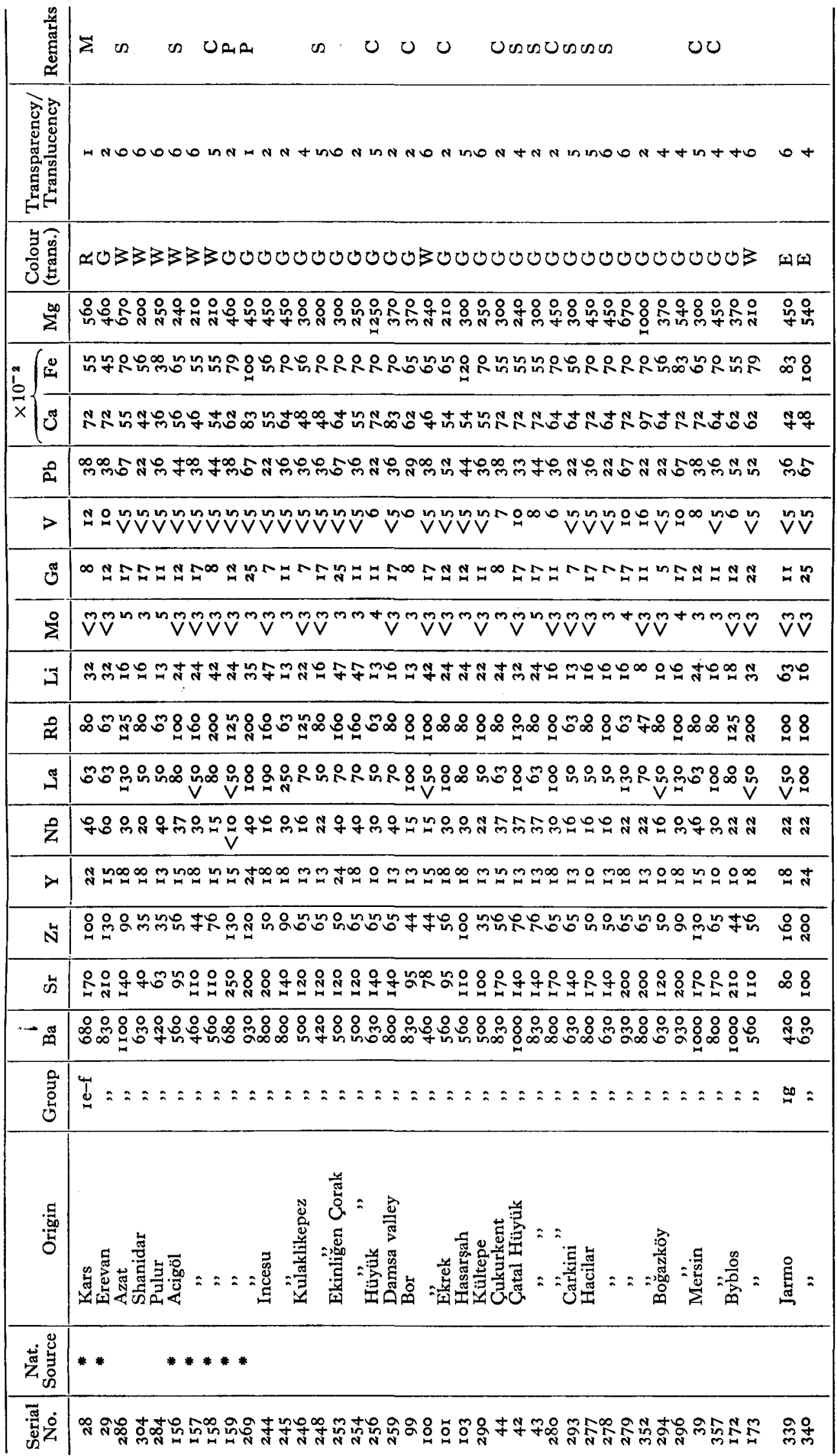




\begin{tabular}{|c|c|c|c|}
\hline 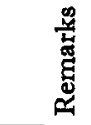 & nU $\operatorname{en}$ & $\begin{array}{ll}y_{1} & \text { inen } \\
0 & 0\end{array}$ & 00 \\
\hline 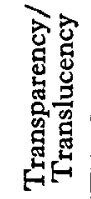 & 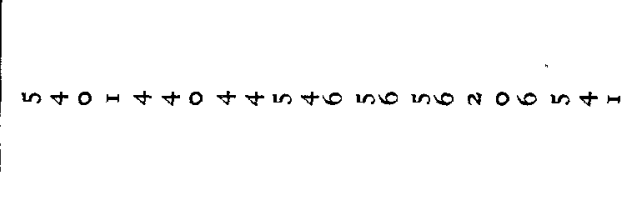 & $00+\infty n+\infty$ & 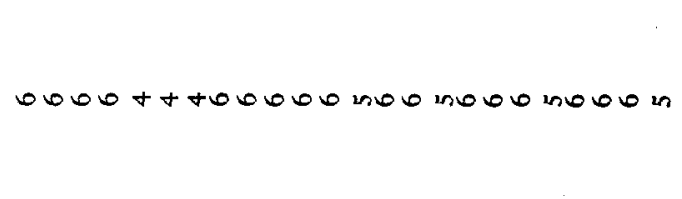 \\
\hline 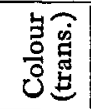 & 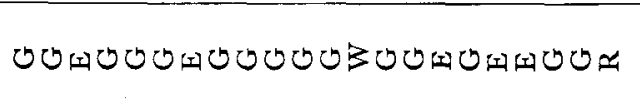 & 00000033 & BOBOOU0000000BOOBBBOBOOB \\
\hline$\sum_{i}^{\infty}$ & 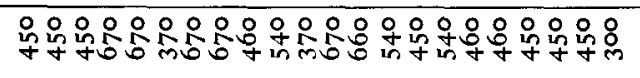 & 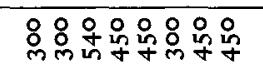 & 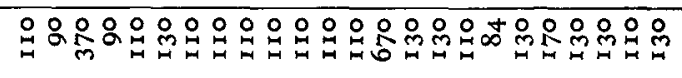 \\
\hline & 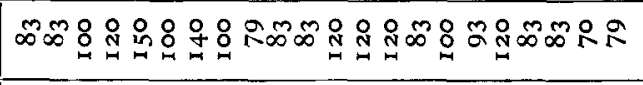 & 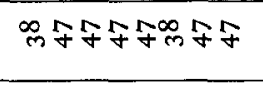 & 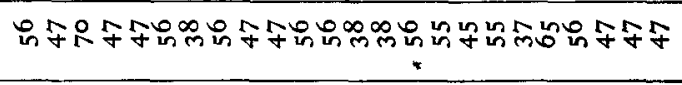 \\
\hline & 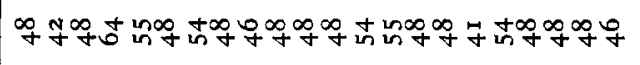 & 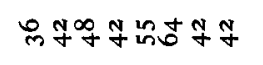 & 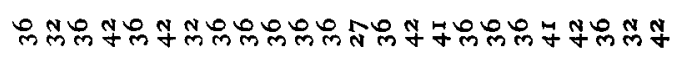 \\
\hline$\hat{\mathrm{A}}$ & 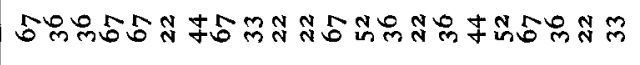 & 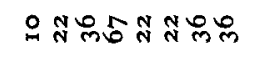 & 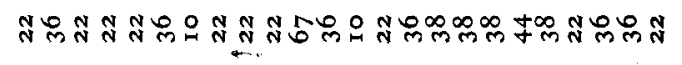 \\
\hline$>$ & 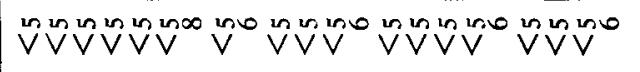 & 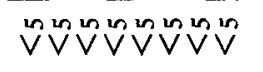 & 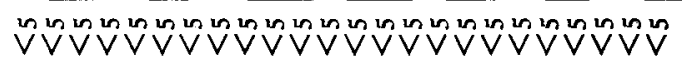 \\
\hline రే & 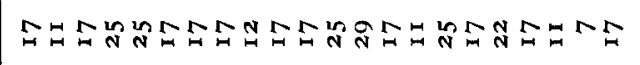 & 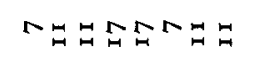 & 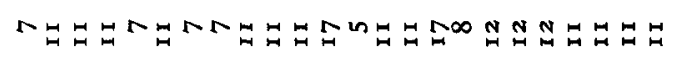 \\
\hline$\sum$ & 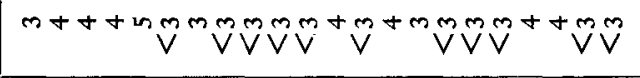 & $\tilde{V} \mathscr{V} \mathscr{V} \mathscr{V} \mathscr{V} \mathscr{V} \mathscr{V} \mathscr{V}$ & 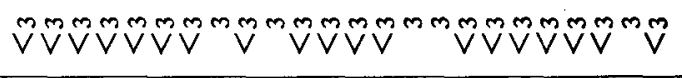 \\
\hline 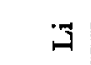 & 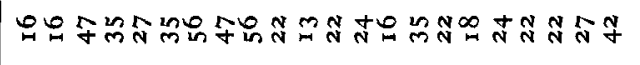 & món & 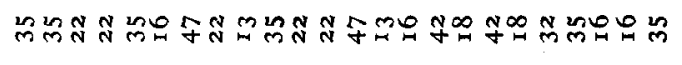 \\
\hline $\overrightarrow{\underline{x}}$ & 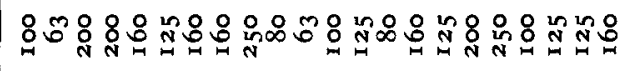 & 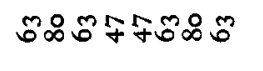 & 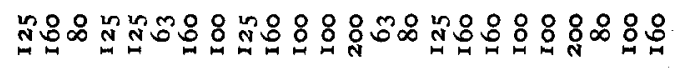 \\
\hline$\stackrel{\widetilde{I}}{\Omega}$ & 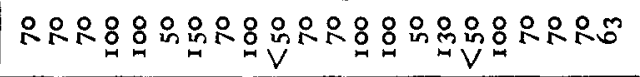 & 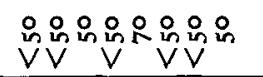 & 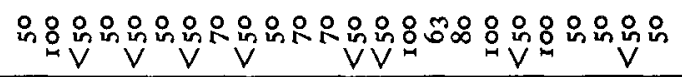 \\
\hline$\hat{z}$ & 고 준 & 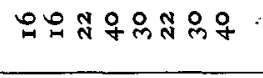 & 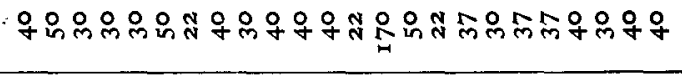 \\
\hline$\lambda$ & 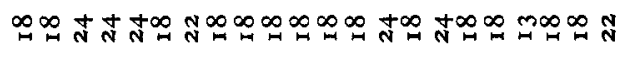 & 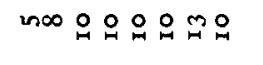 & $\stackrel{\infty}{\infty}$ \\
\hline ลั & 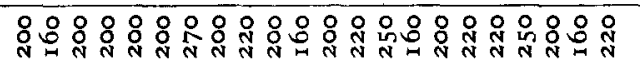 & 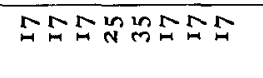 & 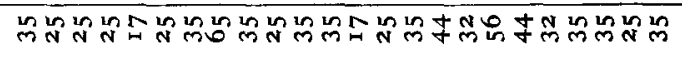 \\
\hline 嵌 & 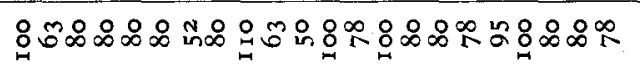 & 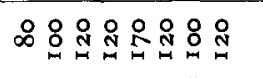 & 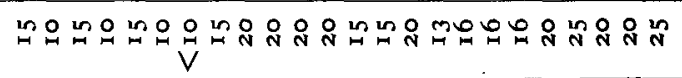 \\
\hline $\mathscr{n}$ & 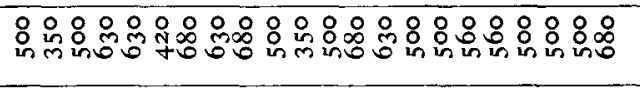 & 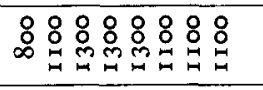 & 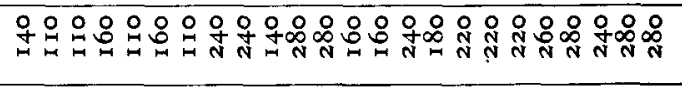 \\
\hline 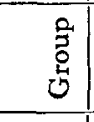 & 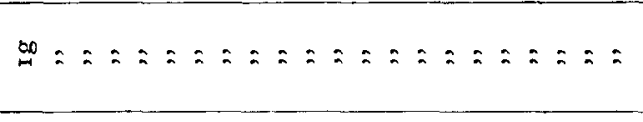 & $\leq:=2=:=2$ & 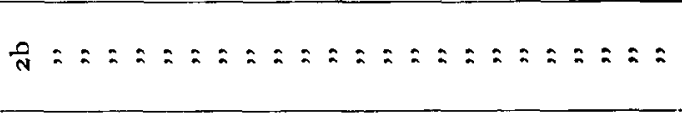 \\
\hline 点 & 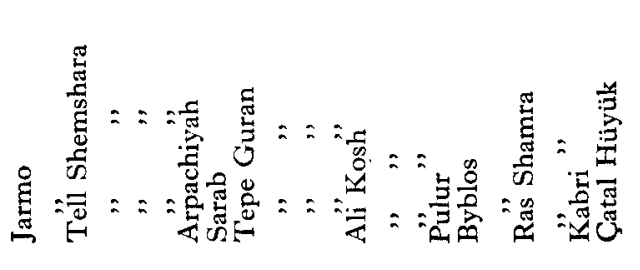 & 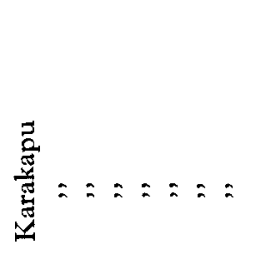 & 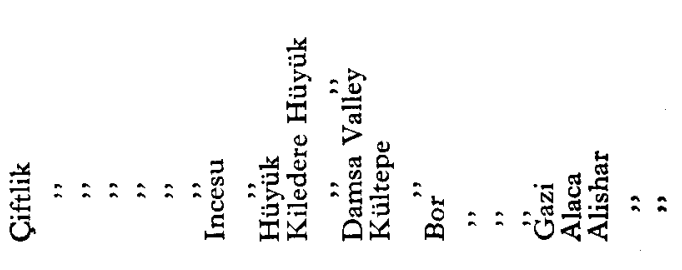 \\
\hline 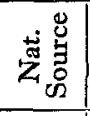 & & & \\
\hline 哥宫 & 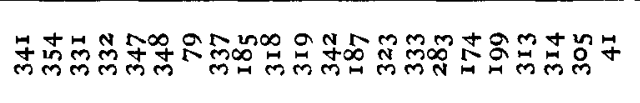 & 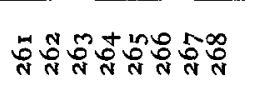 & 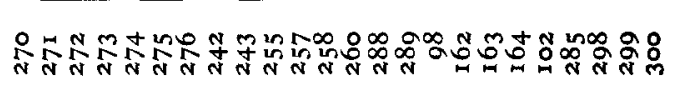 \\
\hline
\end{tabular}




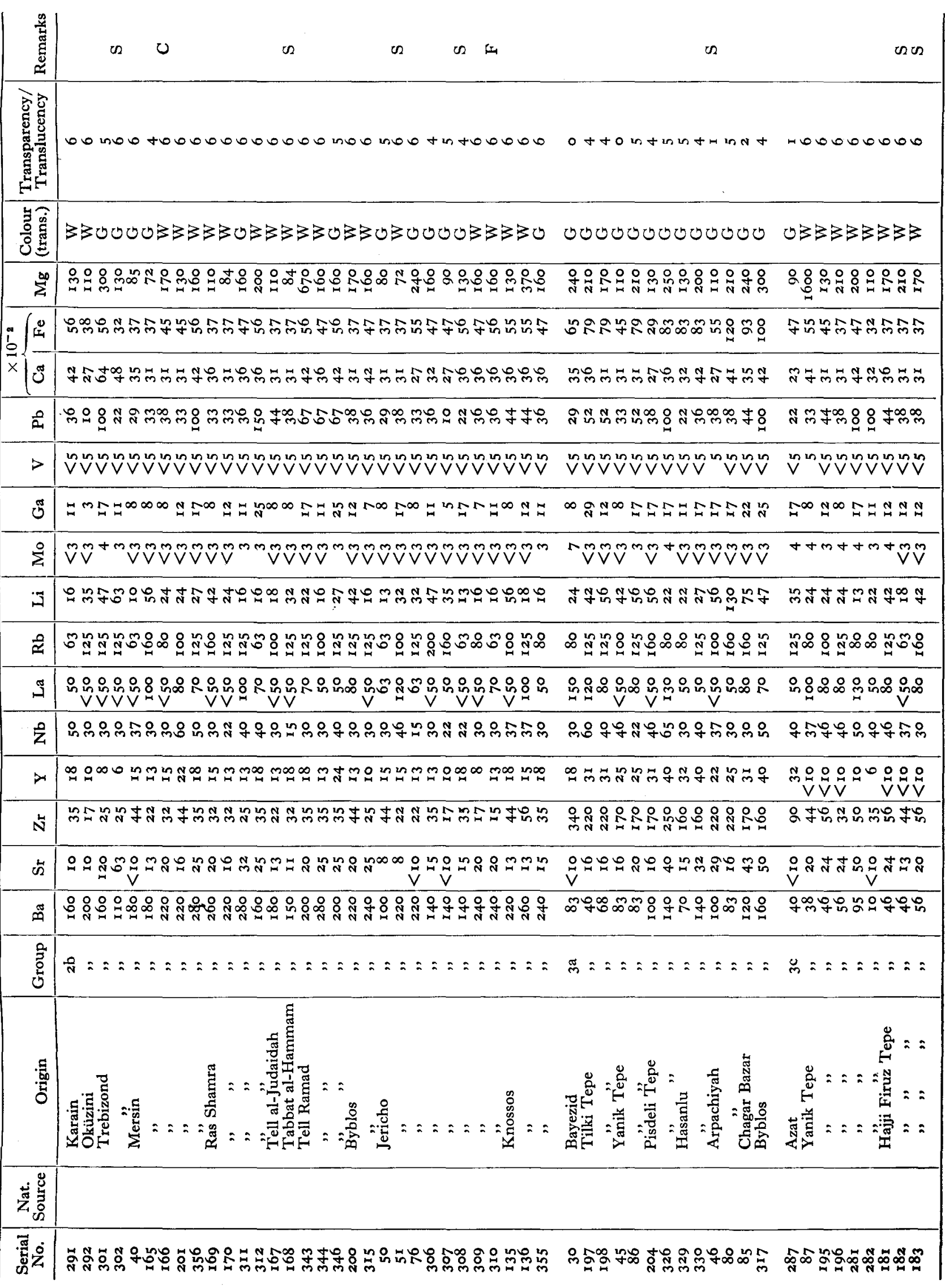




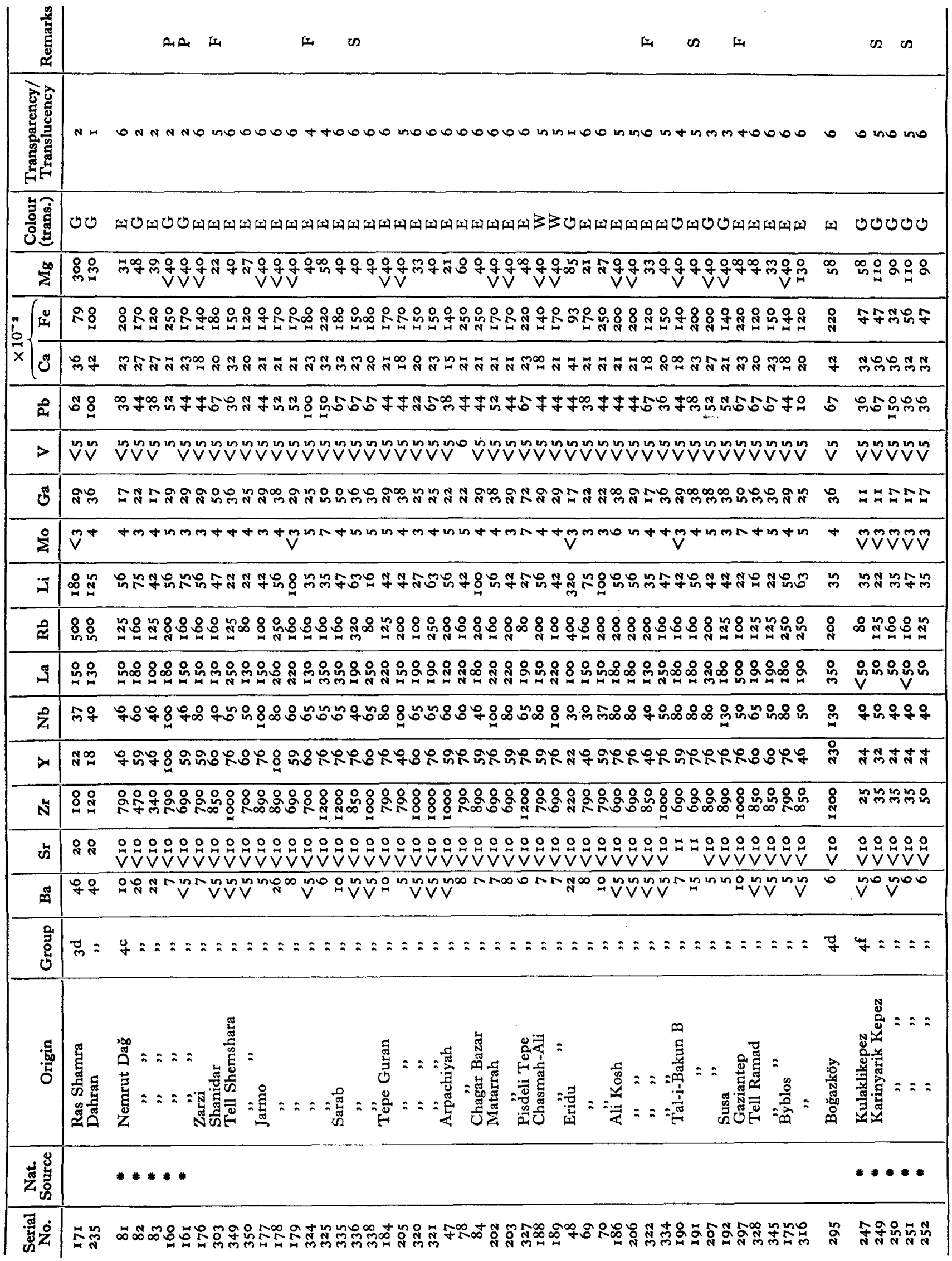

